\title{
BDNF Signaling Promotes Vestibular Compensation by Increasing Neurogenesis and Remodeling the Expression of Potassium-Chloride Cotransporter KCC2 and GABA Receptor in the Vestibular Nuclei
}

\author{
Sophie Dutheil, ${ }^{1}$ Isabelle Watabe, ${ }^{2}$ Karina Sadlaoud, ${ }^{2}{ }^{\circledR}$ Alain Tonetto, ${ }^{3}$ and Brahim Tighilet ${ }^{2}$ \\ ${ }^{1}$ Department of Psychiatry, Yale University School of Medicine, New Haven, Connecticut 06519, ${ }^{2}$ Laboratoire de Neurosciences Intégratives et Adaptatives, \\ UMR 7260 Aix-Marseille Université-CNRS, Fédération de Recherche 3C, 13331 Marseille Cedex 03, France, and ${ }^{3}$ Fédération de Recherche Sciences \\ Chimiques Marseille FR 1739, Pôle PRATIM, 13331 Marseille Cedex 03, France
}

Reactive cell proliferation occurs rapidly in the cat vestibular nuclei (VN) after unilateral vestibular neurectomy (UVN) and has been reported to facilitate the recovery of posturo-locomotor functions. Interestingly, whereas animals experience impairments for several weeks, extraordinary plasticity mechanisms take place in the local microenvironment of the VN: newborn cells survive and acquire different phenotypes, such as microglia, astrocytes, or GABAergic neurons, whereas animals eventually recover completely from their lesion-induced deficits. Because brain-derived neurotrophic factor (BDNF) can modulate vestibular functional recovery and neurogenesis in mammals, in this study, we examined the effect of BDNF chronic intracerebroventricular infusion versus K252a (a Trk receptor antagonist) in our UVN model. Results showed that long-term intracerebroventricular infusion of BDNF accelerated the restoration of vestibular functions and significantly increased UVN-induced neurogenesis, whereas K252a blocked that effect and drastically delayed and prevented the complete restoration of vestibular functions. Further, because the level of excitability in the deafferented VN is correlated with behavioral recovery, we examined the state of neuronal excitability using two specific markers: the cation-chloride cotransporter KCC2 (which determines the hyperpolarizing action of GABA) and $\mathrm{GABA}_{\mathrm{A}}$ receptors. We report for the first time that, during an early time window after UVN, significant BDNF-dependent remodeling of excitability markers occurs in the brainstem. These data suggest that GABA acquires a transient depolarizing action during recovery from UVN, which potentiates the observed reactive neurogenesis and accelerates vestibular functional recovery. These findings suggest that BDNF and/or KCC2 could represent novel treatment strategies for vestibular pathologies.

Key words: BDNF; GABA; gliogenesis; KCC2; neurogenesis; vestibular compensation

Significance Statement

In this study, we report for the first time that brain-derived neurotrophic factor potentiates vestibular neurogenesis and significantly accelerates functional recovery after unilateral vestibular injury. We also show that specific markers of excitability, the potassium-chloride cotransporter $\mathrm{KCC} 2$ and $\mathrm{GABA}_{\mathrm{A}}$ receptors, undergo remarkable fluctuations within vestibular nuclei (VN), strongly suggesting that GABA acquires a transient depolarizing action in the $\mathrm{VN}$ during the recovery period. This novel plasticity mechanism could explain in part how the system returns to electrophysiological homeostasis between the deafferented and intact $\mathrm{VN}$, considered in the literature to be a key parameter of vestibular compensation. In this context, our results open new perspectives for the development of therapeutic approaches to alleviate the vestibular symptoms and favor vestibular function recovery.

\section{Introduction}

Cell proliferation in the adult mammal sometimes occurs after lesions or pathological injury to the CNS, but these immature new cells rarely provide any functional benefit. In addition, it is rare for newly generated cells to differentiate into neurons in the adult mammal without the assistance of drug treatment and it is even rarer to observe a complete recovery of function within a few

This work was supported by the Ministère de l'enseignement supérieur et de la recherche and the Centre National de la Recherche Scientifique (Unité Mixte de Recherche 7260 Aix-Marseille Université). We thank Dr. Alexandra Thomas from Yale University for reviewing and improving this manuscript, Valérie Gilbert and Elodie Mansour for taking care of the animals, and Abdessadek El Ahmadi for expertise in statistical analysis. 
weeks. However, this unusual generative and restorative process, which is more typical of the developing brain, happens after vestibular loss in the adult cat's brain.

Sudden, unilateral vestibular lesion abruptly shuts down the spontaneous resting activity of the vestibular nuclei (VN) neurons of the brainstem on the damaged side, resulting in an imbalance with the intact contralateral VN neurons (Zennou-Azogui et al., 1993; Ris et al., 1995; Ris and Godaux, 1998; Vidal et al., 1998). In a wide variety of species, this imbalance produces diverse symptoms such as balance and gait problems, oscillopsia, spontaneous nystagmus, vegetative disorders including nausea, and other severe impairments (Cass and Goshgarian, 1990; Lacour, 2006). These symptoms are described by patients as extremely unpleasant, but in most cases, they last a few weeks and ameliorate over time in a process called vestibular compensation (Smith and Darlington, 1991; Dieringer, 1995; Vidal et al., 1998; Lacour and Tighilet, 2010). This functional recovery involves sensory and behavioral substitution processes, which contribute to the recovery of dynamic functions, and plasticity mechanisms sustaining the restoration of activity between the deafferented and the intact $\mathrm{VN}$, which leads to the recovery of the static functions of the vestibular system (Lacour and Tighilet, 2010). Many neuroplasticity mechanisms have been described to support vestibular compensation, such as changes in transcription factors expression, alteration in neurotransmitter and hormonal systems, changes in neurotrophins and their receptors, modifications of the density of membrane receptors, and astrocyte and microglial reactions (Lacour and Tighilet, 2010). Interestingly, we were the first to demonstrate that a unilateral vestibular neurectomy (UVN) induces a reactive neurogenesis in the $\mathrm{VN}$ of adult cats (Tighilet et al., 2007). In a follow-up study, continuous intracerebroventricular administration of an antimitotic drug immediately after UVN completely blocked the reactive cell proliferation and delayed 3-fold the recovery of posturo-locomotor functions (Dutheil et al., 2009), indicating that UVN-induced newborn cells contribute to behavioral recovery. In another study that confirmed previous results, we reported that GABA is a major regulator of vestibular compensation, not only by coordinating cellular events-including the different steps of reactive neurogenesis- but also by regulating the speed of recovery of posturo-locomotor functions (Dutheil et al., 2013).

Brain-derived neurotrophic factor (BDNF), a member of the neurotrophin family of proteins, has been shown to promote neurite outgrowth, cell survival, differentiation, migration, and activity-dependent neuroplasticity in the CNS and peripheral nervous system (Greenberg et al., 2009; Park and Poo, 2013). In the context of adult hippocampal neurogenesis, BDNF is known to influence neuronal activity through GABA-mediated effects (Lee et al., 2002; Sairanen et al., 2005; Bergami et al., 2008; Waterhouse et al., 2012). Interestingly, BDNF, through its associated tyrosine kinase $\mathrm{B}$ receptor (TrkB), is also necessary for the normal development of the vestibular system (Ernfors et al., 1994; Schimmang et al., 1995; Fritzsch et al., 1997; Lucas et al., 2014) and for fine vestibular compensation in adult mammals (Bolger et al., 1999; Maingay et al., 2000; Li et al., 2001). Based on this

The authors declare no competing financial interests.

S.D.'s temporary affiliation was Laboratory of Molecular Psychiatry, Department of Psychiatry, Yale University School of Medicine, 34 Park Street, New Haven, CT 06508, USA.

Correspondence should be addressed to Brahim Tighilet, Laboratoire de Neurosciences Intégratives et Adaptatives, UMR 7260 Aix-Marseille Université-CNRS, Fédération de Recherche 3C, 3 Place Victor Hugo, 13331 Marseille Cedex 03, France. E-mail: brahim.tighilet@univ-amu.fr.

DOl:10.1523/JNEUROSCI.0945-16.

Copyright $\odot 2016$ the authors $\quad 0270-6474 / 16 / 366200-14 \$ 15.00 / 0$ evidence, the current study sought to determine whether, after vestibular injury, BDNF-TrkB signaling affects the following: (1) the time course of recovery of vestibular functions, (2) postlesion plasticity mechanisms in the deafferented $\mathrm{VN}$, and (3) the expression level of two specific markers of excitability, the $\mathrm{GABA}_{\mathrm{A}}$ receptor $\left(\mathrm{GABA}_{\mathrm{A}} \mathrm{R}\right)$ and the cation-chloride cotransporter KCC2.

\section{Materials and Methods}

\section{Ethics statement}

All experiments were performed in accordance with the National Institutes of Health's Guide for Care and Use of Laboratory Animals (NIH Publication no. 80-23) revised in 1996 for the UK Animals (Scientific Procedures) Act of 1986 and associated guidelines or the Policy on Ethics approved by the Society for Neuroscience in November 1989 and amended in November 1993. Every attempt was made to minimize both the number of animals used and their suffering in this experiment. We selected only the most important post-UVN time delay according to the findings of our previous studies. Animals were housed in a large, confined space with normal diurnal light variations and free access to toys, water, and food.

\section{Surgery and drug protocol}

Adult male cats weighing between 4 and $5 \mathrm{~kg}$ were anesthetized with ketamine (20 mg/kg, i.m.; Rhône Poulenc), received an analgesic (tolfenamic acid, $4 \mathrm{mg} / \mathrm{kg}$, i.m.; Vetoquinol) and were kept at physiological body temperature using a blanket. The vestibular nerve was sectioned on the left side at the postganglion level to leave the auditory division intact after mastoidectomy, partial destruction of the bony labyrinth, and surgical exposure of the internal auditory canal (Xerri and Lacour, 1980). Animals were maintained under antibiotics for $7 \mathrm{~d}$ and the same analgesics for $3 \mathrm{~d}$. The classical postural, locomotor, and oculomotor deficits displayed by the animals in the days after nerve transection were used as criteria indicating the effectiveness of the vestibular nerve lesion. Completeness of vestibular nerve section had been assessed by histological procedures in previous studies (Lacour et al., 1976). For the implantation and use of osmotic minipumps containing saline, BDNF, or TrK antagonist (K252a), concentrations of BDNF and K252a were selected with reference to studies showing the effect of in vivo infusion of BDNF on neurogenesis (Pencea et al., 2001) and vestibular compensation (Maingay et al., 2000). K252a is a BDNF antagonist that has a high affinity for the TrkB receptor and belongs to the K252 family of alkaloid toxins, which are protein kinase inhibitors. BDNF and K252a (Sigma-Aldrich) were diluted to the required concentrations using artificial CSF containing the following (in mM): $124 \mathrm{NaCl}, 5 \mathrm{KCl}, 1.2 \mathrm{KH}_{2} \mathrm{PO}_{4}$, and $1.3 \mathrm{MgSO}_{4}$, tested for $\mathrm{pH}$, and adjusted to a $\mathrm{pH} 7.0$, if necessary. Subcutaneous minipumps (Alzet; flow rate $2.5 \mu \mathrm{l} / \mathrm{h}$ for $30 \mathrm{~d}$ ) were filled with the solution to infuse as described previously (Dutheil et al., 2009, 2013).

\section{Study design}

To determine the effects of BDNF or K252a infusion after UVN on the different steps of reactive neurogenesis at the cellular level and on the time course of the cats' recovery at a behavioral level (see Fig. 1A), we studied 10 groups of male adult cats. Based on our previous findings regarding the temporal expression pattern of neurogenesis in the VN (Tighilet et al., 2007), two main time points were chosen: (1) $3 \mathrm{~d}$ after UVN to allow us to examine the cell proliferation at its highest expression and (2) $30 \mathrm{~d}$ after UVN while BrdU was injected $3 \mathrm{~d}$ after UVN to study the survival and the differentiation of the proliferating cells in reaction to the lesion. More specifically, the different groups were as follows: (1) sham group: the animals (Group 1, $n=4$ ) were submitted to anesthesia and the same surgical approach as UVN without sectioning the nerve and immediately received a continuous $0.9 \% \mathrm{NaCl}$ infusion. These animals were killed $30 \mathrm{~d}$ later; (2) UVN-NaCl group: animals underwent UVN with continuous $\mathrm{NaCl}$ infusion and then received a BrdU injection (200 $\mathrm{mg} / \mathrm{kg}$, i.p.) and killed either $3 \mathrm{~d}$ later, when cell proliferation reached a peak (Group 2, $n=4$ ), or $30 \mathrm{~d}$ later to study the survival and the differentiation of the proliferating cells (Group 3, $n=4$ ); (3) UVN-BDNF group: animals underwent UVN with continuous BDNF infusion, received a BrdU injection, and were killed 3 d later (Group 4, $n=4$ ) or $30 \mathrm{~d}$ 
Table 1. Antibodies and methods of detection

\begin{tabular}{lll}
\hline Marker & Primary antibody & Secondary antibody \\
\hline BrdU & Mouse, 1:100, Dako & Technique/coloration \\
GFAP & Rabbit, 1:200, Dako & Horse anti-mouse, 1:200, Vector Laboratories \\
GAD67 & Mouse, 1:1000, Chemicon & Goat anti-rabbit, 1:200, Vector Laboratories \\
BrdU & Rat, 1:100, 0xford Biotech & Horse anti-mouse, 1:200, Vector Laboratories \\
GFAP & Rabbit, 1:200, Dako & Rabbit anti-rat, 1:200, Interchim \\
GAD67 & Mouse, 1:100, Chemicon & Goat anti-rabbit, 1:200, Interchim \\
NeuN & Mouse, 1:100, Chemicon & Rabbit anti-mouse, 1:200, Interchim \\
IBA1 & Rabbit, 1:2000, Wako & Rabbit anti-mouse, 1:200, Interchim \\
ChAT & Goat, 1:5000, Chemicon & Goat anti-rabbit, 1:200, Interchim \\
KCC2 & Rabbit, 1:250, Millipore & Donkey anti-goat, 1:2000, Jackson ImmunoResearch \\
GABAA & Mouse, 1:100, US Biol Life & Donkey anti-rabbit, 1:500, Jackson ImmunoResearch \\
\hline
\end{tabular}

Shown are the combination and sequential processing of primary and secondary antibodies used for immunohistochemical and dual immunofluorescent stainings for BrdU, NeuN, GAD67, ChAT, GABA ${ }_{A}$ receptor, KCC2, GFAP, or IBA1.

later (Group 5, $n=4$ ); and (4) UVN-K252a group: animals underwent UVN with continuous K252a infusion, received a BrdU injection, and were killed $3 \mathrm{~d}$ later (Group 6, $n=4$ ) or $30 \mathrm{~d}$ later (Group 7, $n=4$ ). The two postlesion survival periods (days 3 and 30 ) were selected on the basis of our previous data (Tighilet et al., 2007). Concerning the behavioral investigations, 12 UVN cats were used for this study and received continuous infusion of $\mathrm{NaCl}$ (Group 8, $n=4$ ), BDNF (Group 9, $n=4$ ), or K252a (Group 10, $n=4$ ) after the surgery. Because the Alzet minipump was filled with enough drug to be delivered continuously for $30 \mathrm{~d}$, animals undergoing behavioral investigation stopped getting $\mathrm{NaCl}$, BDNF, or K252a delivered after 1 month and continued being tested until they reached their pre-UVN performance or $160 \mathrm{~d}$ after UVN for the UVNK252a group (Group 10).

\section{Cellular investigations}

Tissue preparation. As described in a previous study (Dutheil et al., 2013), $\mathrm{BrdU}(10 \mathrm{mg} / \mathrm{ml}$; Sigma-Aldrich) was dissolved in a solution of $\mathrm{NaCl}$ $0.9 \%$ heated to $56^{\circ} \mathrm{C}$ and injected into animals $(200 \mathrm{mg} / \mathrm{kg})$. BrdU doses were not likely to generate side effects, but were sufficient to mark the cells in S-phase synthesizing DNA. Before BrdU administration, the cats in each group were deeply anesthetized with ketamine dihydrochoride (20 mg/kg, i.m.; Merial). The last hour before they were killed, animals were deeply anesthetized with ketamine dihydrochloride $(20 \mathrm{mg} / \mathrm{kg}$, i.m.; Merial) and then perfused with $0.9 \% \mathrm{NaCl}(1 \mathrm{~L}$ per animal), followed by freshly prepared paraformaldehyde $4 \%$ solution ( $2 \mathrm{~L}$ per animal). After removal from the skull, brains were cut into several blocks containing the VN. Blocks were rapidly frozen with dry ice and stored at $-80^{\circ} \mathrm{C}$. Coronal sections (40 $\mu \mathrm{m}$ thick) were cut in a cryostat (Leica) for immunochemistry.

Immunochemistry. Immunochemical labeling was performed according to previously validated protocols (Brezun and Daszuta, 2000; Tighilet et al., 2007). The differentiation of the newly generated cells was analyzed in the UVN-NaCl, UVN-BDNF, and UVN-K252a groups injected with BrdU $3 \mathrm{~d}$ after UVN and killed after 1 month. Double immunofluorescence-stained sections incubated with BrdU and one of four antibodies were used: NeuN, a postmitotic neuronal nuclei marker expressed in most neurons; the glial fibrillary acidic protein (GFAP), a specific type of intermediate filament protein used as an astrocyte marker; IBA1, an ionized calcium-binding adapter molecule 1 that is specific to microglia and macrophages, but not cross-reactive with neurons and astrocytes; GAD 67, the enzyme that catalyzes the decarboxylation of glutamate to GABA and expressed in GABAergic neurons; and ChAT, a transferase enzyme responsible for the synthesis of the neurotransmitter acetylcholine and expressed in cholinergic neurons. Each antibody was processed sequentially, the differentiation marker detection first and then the BrdU labeling. For fluorescence labeling, sections were incubated with a secondary antibody coverslipped in Mowiol. Differentiation of the newly generated cells was analyzed with doublelabeling analysis performed using confocal imaging with a Zeiss LM 710 NLO laser-scanning microscope equipped with a $63 \mathrm{x} / 1.32$ numerical aperture (NA) oil-immersion lens. The fields of view were then examined by confocal microscopy, and $1 \mu \mathrm{m}$-step $Z$-series were obtained. For $\mathrm{GABA}_{\mathrm{A}} \mathrm{R}$ and KCC2 immunohistochemistry, sections were incubated overnight at $22^{\circ} \mathrm{C}$ in a mixture of affinity-purified rabbit KCC2-specific polyclonal antibody and the monoclonal mouse antibody against $\mathrm{GABA}_{\mathrm{A}} \mathrm{R} \beta$ 2,3. Labeling was revealed with a mixture of donkey Cy3conjugated rabbit-specific antibody and donkey Alexa Fluor 488conjugated mouse-specific antibody and coverslips were mounted with a gelatinous aqueous medium. The patterns of immunolabeling were analyzed with a laser scanning confocal microscope (Zeiss LSM 710 META) at high magnification (Plan Apochromat $63 \times 1.4 \mathrm{NA}$ oil-immersion objective). The optimal antibody dilutions and staining procedures are described in Table 1.

\section{Cell-counting method and quantification of $G A B A_{A} R$ and KCC2 immunoreactivity}

Cell counts were performed according to a previously validated protocol (Dutheil et al., 2009, 2011). The VN were identified through Berman's stereotaxic atlas (Berman, 1968). $\mathrm{BrdU}^{+}, \mathrm{GFAP}^{+}, \mathrm{IBA}^{+}, \mathrm{ChAT}^{+} 7^{+}$, and $\mathrm{GAD}^{+} 7^{+}$cells were quantified on both sides (left/right: shamoperated cats; ipsilateral/contralateral: UVN-lesioned cats) for each VN (medial, inferior, superior, and lateral VN: MVN, IVN, SVN, and LVN, respectively) from selected serial frontal sections collected from the dorsal (5.2) to the caudal (12.1) part of the brainstem and depending on the size and the rostrocaudal length of each $\mathrm{VN}$. The cell count was done with a Nikon microscope (Eclipse 80i) equipped with a motorized $X-Y$-Zsensitive stage and a video camera connected to a computerized image analysis system (Mercator; Explora Nova). The total number of immunolabeled cells was estimated using the optical fractionator method (West et al., 1991). For quantification of KCC2 and GABA $A_{A}$ R immunohistochemistry, double fluorescence labeling was captured using framechannel mode to avoid any cross-talk between the channels. Each optical section resulted from two scanning averages. Excitation of the fluorochromes was performed with an argon ion laser set at $488 \mathrm{~nm}$ and a helium/neon laser set at $575 \mathrm{~nm}$. At high magnification, we only scanned the lateral VN, which is constituted by giant neurons (100 $\mu \mathrm{m}$ average) with visible nuclei and, for each soma, we digitized stacks of $1-\mu \mathrm{m}$-thick optical sections. We overlayed the internal and external borders, and digitized intensity measurements of $\mathrm{KCC} 2$ and $\mathrm{GABA}_{\mathrm{A}} \mathrm{R}$ labeling using ZEN 2012 software. This method of quantification has been validated in other studies (Boulenguez et al., 2010; Sadlaoud et al., 2010; Bos et al., 2013).

\section{Behavioral investigations}

Spontaneous nystagmus recovery. The day after UVN, each cat of the behavioral cohort was placed on an apparatus with its head fixed, thus maintaining the horizontal semicircular canals in the horizontal plane. The frequency of the horizontal spontaneous nystagmus was measured in the light as the number of quick phase beats toward the contralateral side relative to UVN in $10 \mathrm{~s}$ (five repeated measures per animal per sampling time) with a video camera (Sony HDV).

Posture recovery. Posture deficits and recovery were evaluated by measuring the surface delimited by the four legs of the cats while they were standing erect at rest on a device with a graduated transparent floor that allowed them to be photographed from underneath. Five repeated measurements were done for each cat tested at each preoperative and post- 


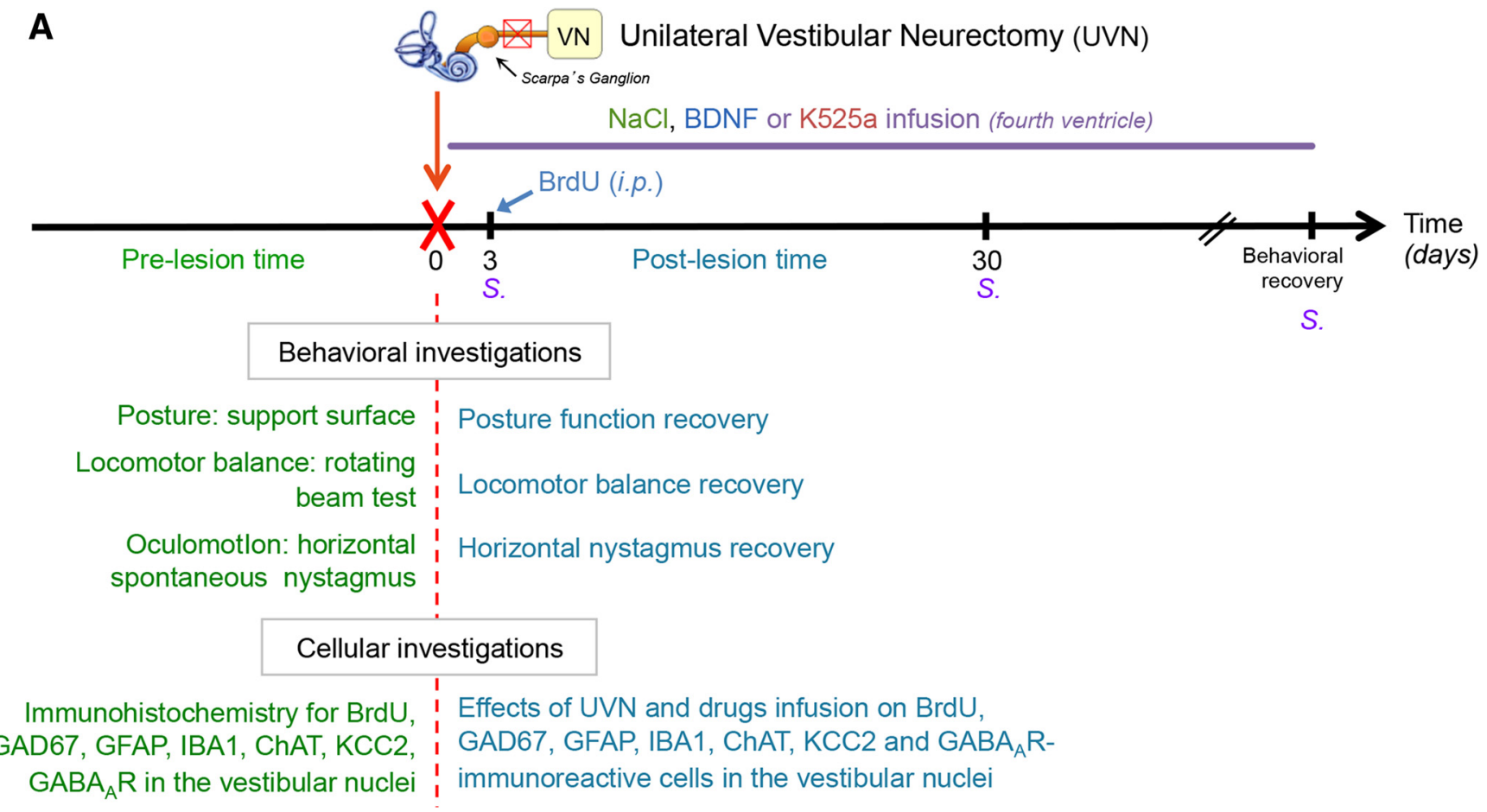

\section{B}

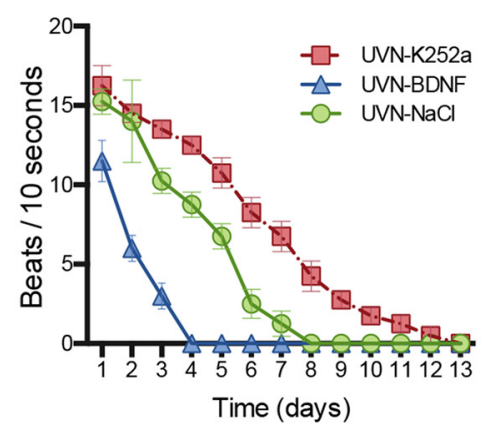

C

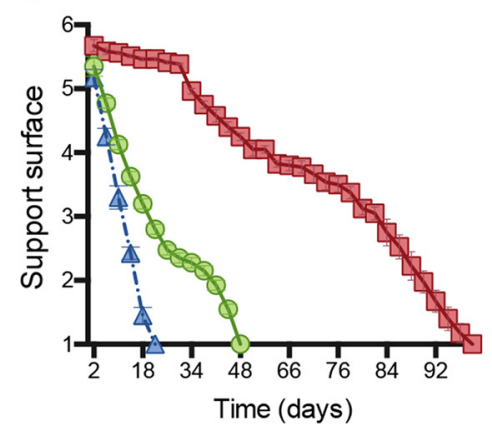

D

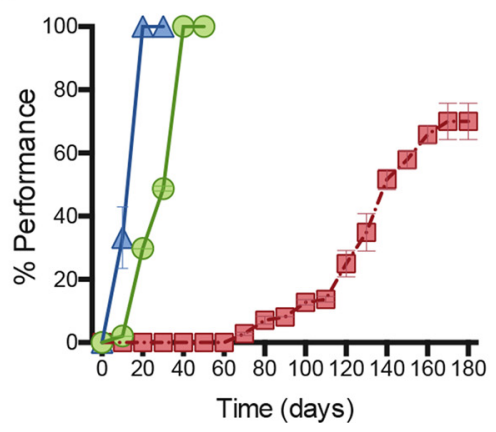

Figure 1. After UVN, behavioral recovery, reactive cell proliferation, and cell survival are altered by BDNF and K252a infusions in the deafferented VN. $A$, Experimental protocol to study the effects of continuous infusion in the fourth ventricle of BDNF or K252a (a TrK receptor blocker) at the cellular level, accompanied by behavioral analyses ( $n=4$ animals per group). B, Curves illustrating the time course of disappearance of horizontal spontaneous nystagmus frequency for each group of cats at different postoperative days. $C$, Curves indicating the mean postoperative recovery of the support surface after vestibular damage. $\boldsymbol{D}$, Curves indicating the mean postoperative recovery of the equilibrium function after vestibular damage. The MaxP is defined as the highest beam rotation speed that did not lead to a fall on four consecutive crossings. The curves are expressed in percentage of the preoperative maximal performance as a function of the postoperative time in days.

operative time so that each animal acted as its own control. An average was calculated for each experimental session by an image analysis system (canvas, 9TM; Deneba Software).

Equilibrium function recovery. The rotating beam test was performed according to standard published procedures used in our laboratory (Xerri and Lacour, 1980; Tighilet et al., 2006). Cats were first conditioned to cross over the immobile beam few weeks before surgery and were rewarded by a small piece of food placed in the target compartment. As a rule, rotation velocity of the beam was progressively increased after four consecutive trials without fall. Equilibrium function was quantified by measuring the highest speed of beam rotation that did not induce a fall and was called maximal locomotor balance performance (MaxP). For more details, see Dutheil et al. (2009, 2013).

Statistical analysis of the behavioral and cellular data. Statistical analysis was done with ANOVA to test for changes at the different postlesion delays in the spontaneous nystagmus, the support surface, and the maximal equilibrium performance of the cats. Results were considered significant at $p<0.05$. The statistical analyses of the cellular data were also evaluated by ANOVA to test the effects of the group (UVN-NaCl, UVNBDNF, or UVN-K252a), the structure (MVN, IVN, LVN, SVN), the side (deafferented vs intact) and the postoperative time on BrdU, IBA1, GFAP, ChAT, GAD67, KCC2, and GABA $\mathrm{A}_{\mathrm{A}}$ Rs immunostainings to determine whether there were any interactions between these variables. ANOVA was followed by post hoc analysis with the Scheffé test and multicomparison Fisher's test (StatView II; SAS Institute).

\section{Results}

\section{BDNF signaling is required for behavioral recovery} after UVN

Unilateral vestibular damage results in a constellation of heterogeneous symptoms in mammals: ocular nystagmus (fast phase directed to the intact side), head tilt toward the side of the lesion, postural asymmetry, enhancement of the support surface, and falling to the lesioned side in the first postlesion week in cats. To determine whether BDNF signaling modulates behavioral recovery of animals after UVN, we infused $\mathrm{NaCl}, \mathrm{BDNF}$, or K252a intracerebroventricularly for longitudinal behavioral analyses of Groups 8, 9, and 10 (see "Study design" section and Fig. $1 A$ for more information). 


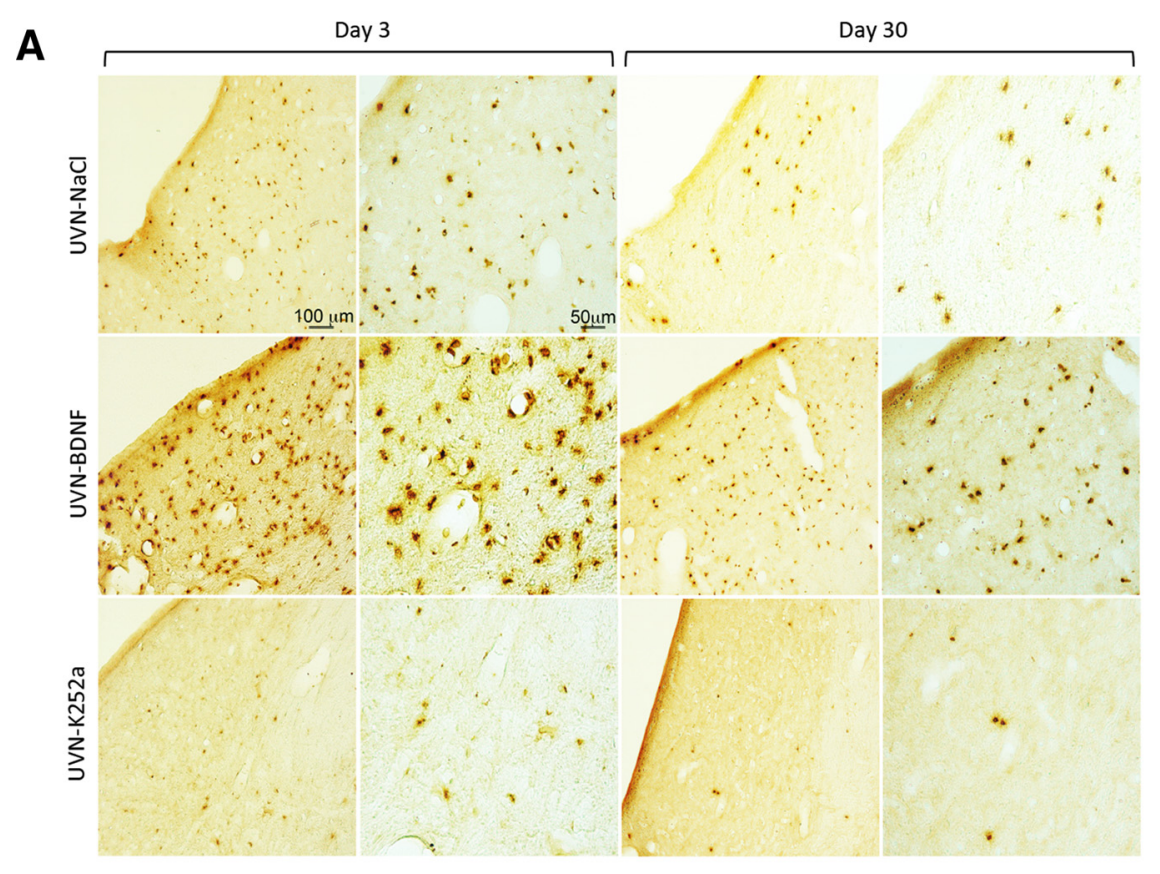

B
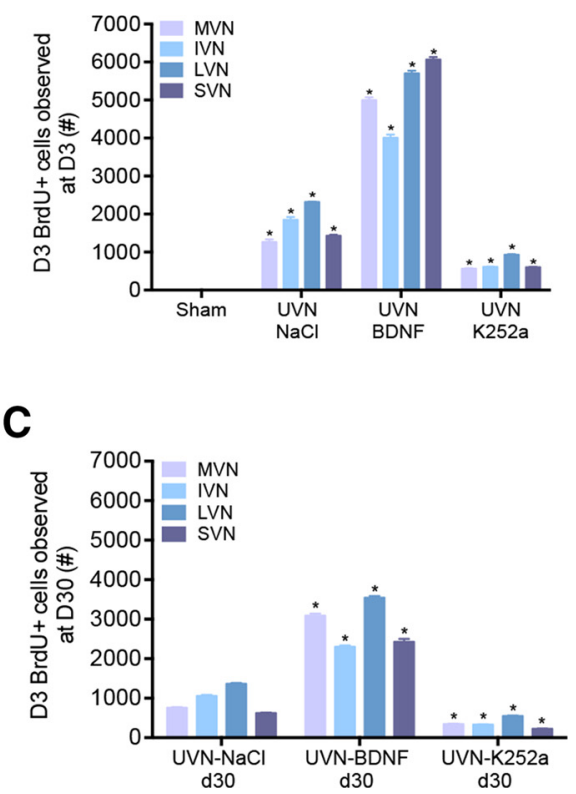

Figure 2. BDNF treatment alters vestibular cell proliferation and cell survival. $A$, Photomicrographs showing BrdU immunostainings in the deafferented MVN 3 or $30 \mathrm{~d}$ after UVN with continuous drug infusion in the fourth ventricle (NaCl, BDNF, or K252a). B, Histograms comparing the mean values (SEM) of the number of BrdU ${ }^{+}$cells that incorporated BrdU at day 3 afater UVN. C, Histograms comparing the mean values (SEM) of the number of BrdU ${ }^{+}$cells that incorporated BrdU at day 3 and survived $27 \mathrm{~d}$ later in the different deafferented VN. ${ }^{*} p<0.0001$ compared with the same VN in other groups.

\begin{abstract}
Nystagmus
Unilateral vestibular damage produces a spontaneous nystagmus. BDNF infusion led to a decrease in the number of nystagmus beats at day 3 compared with $\mathrm{K} 252 \mathrm{a}-$ and $\mathrm{NaCl}$-treated cats (vehicle: 10.25 beats/10 s, BDNF: 3 beats/10 s, K252a: 13.5 beats $/ 10 \mathrm{~s}, p<0.0001$; Fig. $1 B$ ). Overall, the total disappearance of spontaneous horizontal nystagmus was faster for the UVNBDNF group ( $4 \mathrm{~d}$ ) than for the vehicle group ( $8 \mathrm{~d}$ ) and the K252atreated group $(13 \mathrm{~d})(p<0.0001)$.
\end{abstract}

\section{Posture function recovery}

Unilateral vestibular damage leads to an increased support surface delimited by the four paw pads of four-footed animals. This parameter reflects a good estimation of postural stability and recovery. As a rule, the surface was $\sim 50-100 \mathrm{~cm}^{2}$ in cats before UVN and significantly increased in the days after unilateral vestibular lesion. Return to pre-UVN control values, normalized to 1 , was faster when animals were infused with BDNF (22 d) rather than $\mathrm{NaCl}$ (48 d). K252a drastically delayed the return to control values: cats of this group recovered preoperative values only after $98 \mathrm{~d}$ (Fig. 1C). Two-way ANOVA established significant effects depending on the groups $(p<0.0001)$, the postlesion time $(p<0.0001)$, and the interaction between these two factors $(p<0.0001)$.

\section{Locomotor balance recovery}

The rotating beam experimental device test provides a reliable behavioral measure of locomotor balance function consistent with the time lag necessary for the progressive disappearance of the posturo-locomotor vestibular symptoms experienced after vestibular damage. The role of BDNF in the posturo-locomotor recovery was tested in cats exposed to pre-UVN rotating beam training. Congruent with the data of the posture function and the nystagmus, BDNF improved substantially the dynamic locomotor balance of the animals, which were able to cross the rotating beam at their maximal performance after only $18 \mathrm{~d}$ after UVN, whereas $\mathrm{NaCl}$ animals reached the same performance at $36 \mathrm{~d}$. In contrast, cats infused with K252a could not walk on the beam rotating at the lowest speed until $66 \mathrm{~d}$ after UVN and finally reached a plateau of $70 \%$ of their MaxP at $160 \mathrm{~d}$ (Fig. 1D). Twoway ANOVA showed significant effects depending on the drug infused $(p<0.0001)$, the postlesion time $(p<0.0001)$, and the interaction between these two factors $(p<0.0001)$.

\section{BDNF expression influence cell proliferation and survival of new cells in the $\mathrm{VN}$ after vestibular damage}

Based on our previous studies (Dutheil et al., 2009, 2013), exogenous $\mathrm{NaCl}$, BDNF or $\mathrm{K} 252 \mathrm{a}$ was continuously delivered (intracerebroventricularly via minipump) immediately after UVN in adult cats to examine postlesion plasticity mechanisms in the VN. We first assessed reactive cell proliferation in the VN (Groups 1, 2,4 , and 6 as described in the "Study design" section) by measuring the number of cells that incorporated the DNA synthesis marker BrdU after short-term infusion (at day 3, when cell proliferation has been described to reach a peak in this model of lesion; Tighilet et al., 2007). Results showed that BDNF increases the number of $\mathrm{BrdU}^{+}$cells by $\sim 4$-fold compared with the UVN$\mathrm{NaCl}$ group $(p<0.0001$; Fig. $2 A, B)$. In contrast, intracerebroventricular administration of the high-affinity $\operatorname{TrK}$ receptor blocker K252a caused an $\sim 2$-fold decrease of the $\mathrm{BrdU}^{+}$cells in all of the deafferented $\mathrm{VN}$ group compared with the UVN-NaCl group $(p<0.0001)$ and, as described previously, we did not observe a significant number of $\mathrm{BrdU}^{+}$cells in sham animals.

Next, to assess the phenotype of the proliferative cells, BrdU was administered $3 \mathrm{~d}$ after UVN and the phenotype of the $\mathrm{BrdU}^{+}$ cells was analyzed $27 \mathrm{~d}$ later (Groups 3, 5, and 7, as described in the "Study design" section). Results showed that a substantial number of cells that had incorporated BrdU at day 3 survived up to $30 \mathrm{~d}$ in the $\mathrm{NaCl}$-infused group. We also observed that $\mathrm{BDNF}$ 
A

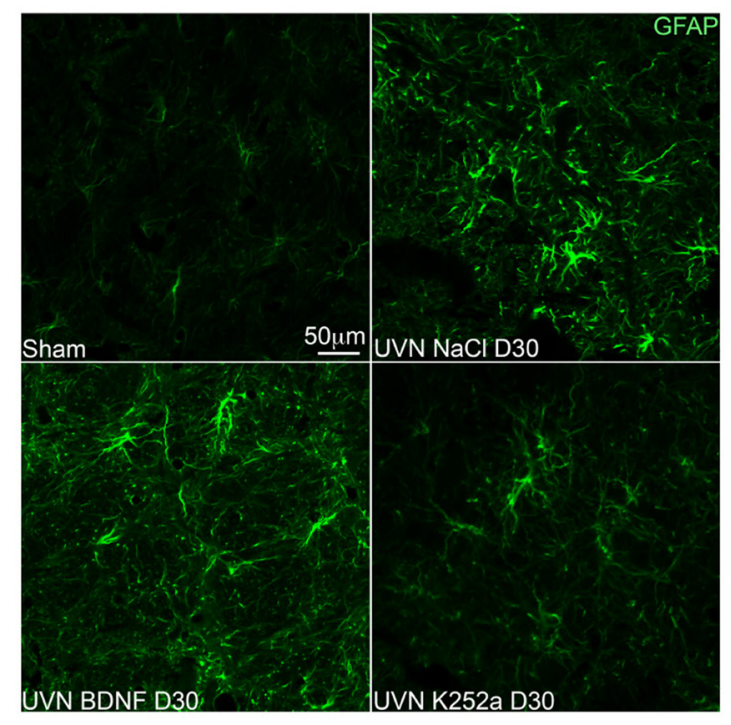

B

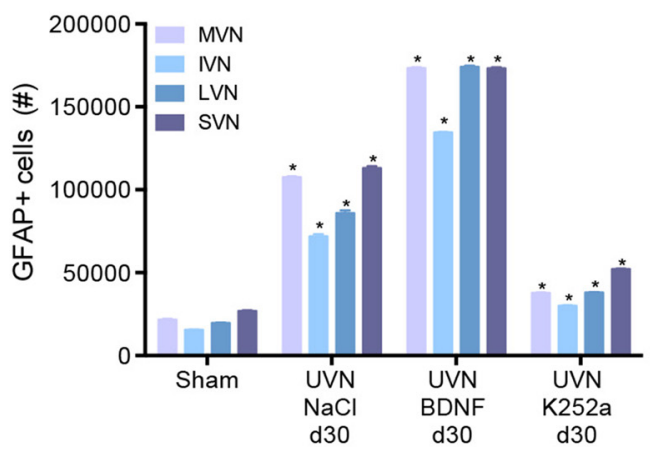

C

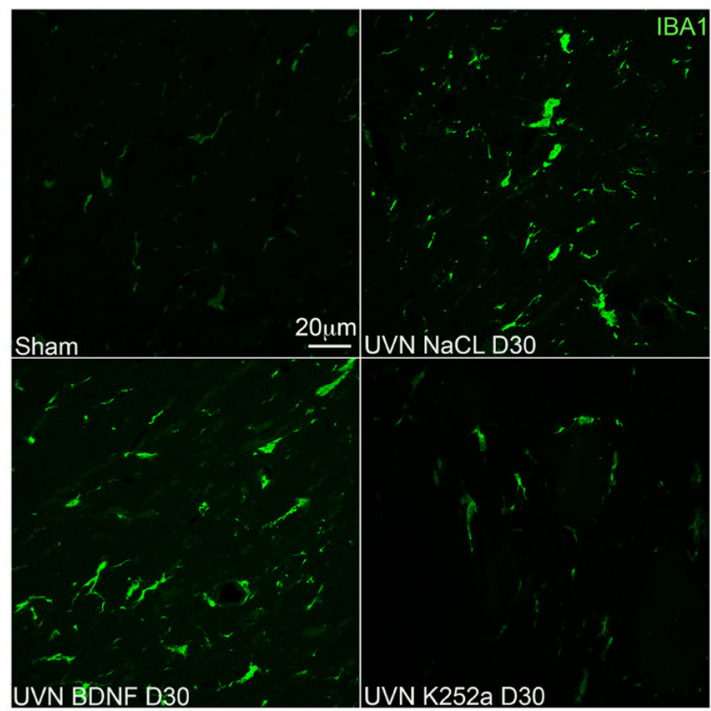

D

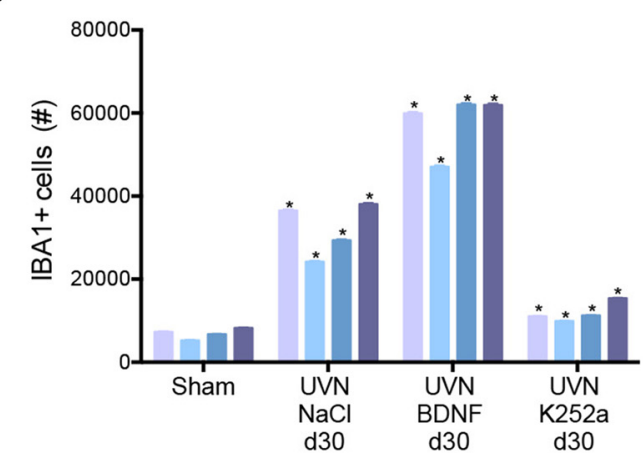

Figure 3. BDNF treatment increases astrocytic and microglial cell population in the VN. $A, C$, lllustrations of GFAP- ${ }^{-}(A)$ or IBA $1^{+}(C)$ cells in the left (lesioned) MVN of sham, UVN-NaCl, UVN-BDNF, and UVN-K252a animals $30 \mathrm{~d}$ after UVN. Scale bars: $\boldsymbol{A}, 50 \mu \mathrm{m} ; \boldsymbol{B}, 20 \mu \mathrm{m} . n=4$ animals per group. $\boldsymbol{B}, \boldsymbol{D}$, Histograms showing the effects of NaCl, BDNF, or K252a continuous infusion on the number of GFAP ${ }^{-}(\boldsymbol{B}){\text { or IBA }{ }^{+}}^{+}(\boldsymbol{D})$ cells in the four VN $30 \mathrm{~d}$ after UVN. Only values recorded on the lesioned side are illustrated and data from both sides of the sham group were pooled for direct comparison with the subgroups of vestibular deafferented cats. SEMs are shown as vertical lines. Analyzes were assessed by ANOVA followed by Scheffe test for all of the VN and all groups $\left({ }^{*} p<0.0001\right.$ vs the same VN of other groups).

strongly increased the number of cells that had survived at this time point (Fig. 2C), whereas K252a blocked this effect, decreasing the number of $\mathrm{BrdU}^{+}$surviving cells by $\sim 2$-fold compared with UVN-NaCl group. Therefore, our results suggest that, after UVN, BDNF treatment facilitates, not only cell proliferation, but also cell survival in the deafferented VN.

\section{BDNF treatment for $\mathbf{3 0} \mathrm{d}$ increases astrocytes and microglia on the deafferented side}

Next, we examined the impact of BDNF on astrocytes and microglia in the deafferented VN. Results showed that BDNF infused continuously for $30 \mathrm{~d}$ significantly increased the average number of GFAP cells in all the VN compared with the sham and the UVN-NaCl groups (average of all VN, sham: 20,876.73 cells, UVN-NaCl: 94,559 cells, UVN-BDNF: 163, 759.09 cells), whereas administration of K252a significantly decreased this population in a proportion almost similar to what is observed in sham cats (UVN-K252a: 39,473.3 cells, $p<$ 0.0001 ; Fig. $3 A, B)$.

We also observed that UVN induced a significant increase in microglial reaction at the day 30 after lesion in all of the deafferented $\mathrm{VN}$ of animals infused with $\mathrm{NaCl}$. This effect was enhanced by BDNF, whereas K252a blocked this effect because we observed a number of $\mathrm{IBA}^{+}$cells almost similar to basal sham conditions (average of all VN, sham: 6880.05 cells, UVN-NaCl: 32,017.93 cells, UVN-BDNF: 57,732.74 cells, UVN-K252: 11,877.71 cells, $p<0.0001$; Fig. $3 C, D)$. Together, these results demonstrate that BDNF is a key modulator of post-UVN local increases in astrocytes and microglia.

BDNF treatment for $30 \mathrm{~d}$ increases the number of cholinergic and GABAergic neurons

To determine whether BDNF influences neuromodulator systems involved in vestibular compensation processes, we used ChAT and GAD67 immunomarkers to label cholinergic and GABAergic neurons in the VN $30 \mathrm{~d}$ after UVN. The results indicated that, in the sham group, the number of $\mathrm{ChAT}^{+}$neurons was moderate and symmetric in both sides of the MVN (60.0 cells). Such proportion was comparable to the intact side of the MVN in all experimental groups (intact side, UVN-NaCl: 65 cells, UVN-BDNF: 68.7 cells, UVN-K252a: 58.0 cells). However, on the deafferented side, the number of $\mathrm{ChAT}^{+}$neurons was significantly increased in the $\mathrm{UVN}-\mathrm{NaCl}$ group and was increased by BDNF (UVN-NaCl: 104.5 cells, UVN-BDNF: 176.8 cells, $p<0.0001$ ), whereas K252a did not have any effect (UVNK252a: 56.8 cells). This suggests that UVN upregulates cholin- 
A

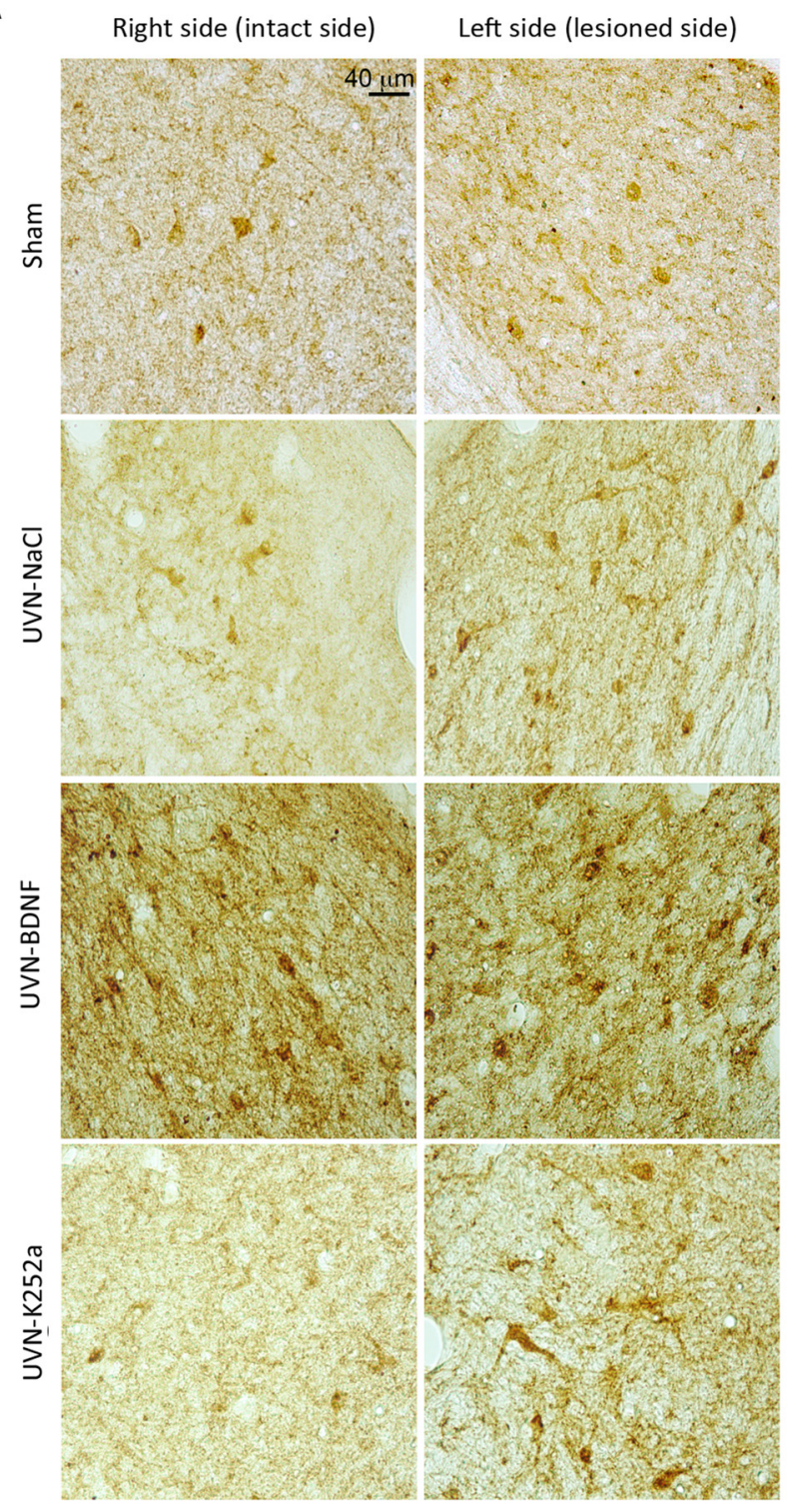

B
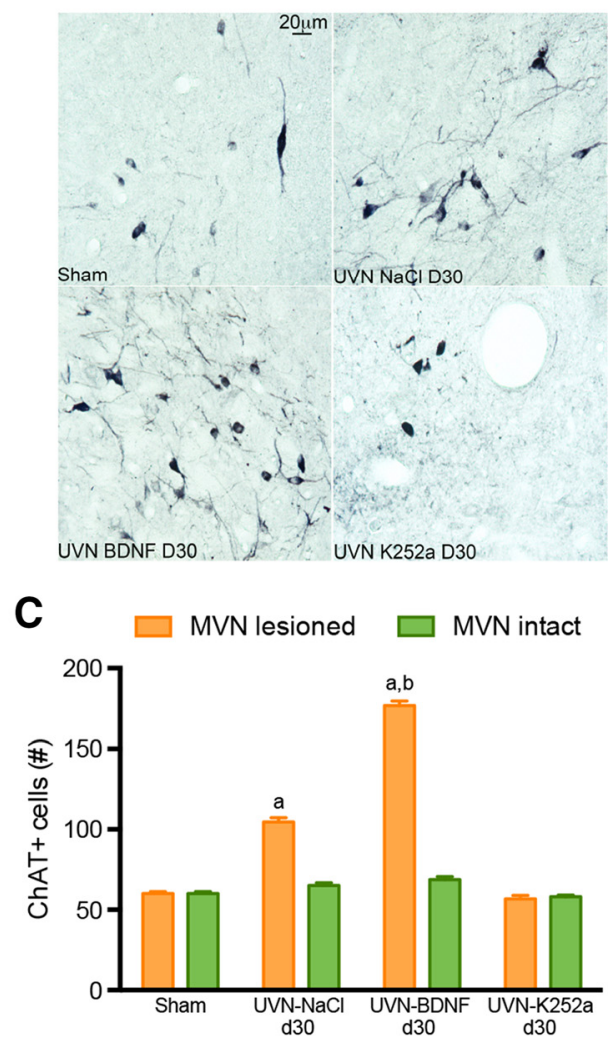

D

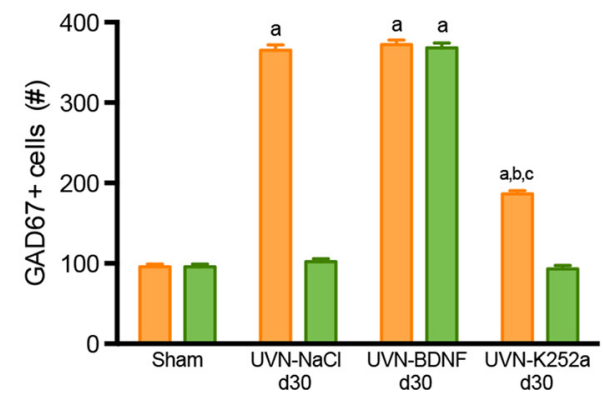

Figure 4. One month after UVN, BDNF treatment increases the number of GABAergic and cholinergic neurons in the VN. $A$, lllustrations of GAD67 immunoreactivity in the in the right (intact) and left (lesioned) MVN of sham, UVN-NaCl, UVN-BDNF, and UVN-K252a animals $30 \mathrm{~d}$ after UVN. Scale bar, $40 \mu \mathrm{m} . n=4$ animals per group. $\boldsymbol{B}$, Illustrations of ChAT immunoreactivity in the left (lesioned) MVN of sham, UVN-NaCl, UVN-BDNF, and UVN-K252a animals $30 \mathrm{~d}$ after UVN. Scale bar, $20 \mu \mathrm{m} . n=4$ animals per group. C, Histograms showing the effects of NaCl, BDNF, or K252a continuous infusion on the number of $\mathrm{ChAT}^{+}$neurons in both right (intact) and left (lesioned) medial VN $30 \mathrm{~d}$ after UVN. D, Histograms showing the effects of NaCl, BDNF, or K252a continuous infusion on the number of GAD67 ${ }^{+}$neurons in both right (intact) and left (lesioned) medial VN $30 \mathrm{~d}$ after UVN. SEMs are shown as vertical lines. Different letters indicate significant differences between groups of animals: a, significantly different from sham non-lesioned group; b, significantly different from UVN-NaCl group; c, significantly different from intact MVN of UVN-K252a group. Analyses were assessed by ANOVA followed by Scheffe test for all of the VN and all groups $(p<0.0001)$.

ergic neurons exclusively on the lesioned side and this effect is reinforced by BDNF but blocked by K252a administration (Fig. $4 B, C$ ).

Although the number of GAD $67^{+}$neurons was moderate and symmetric in both sides of the MVN in the sham group (95.9 cells), $\mathrm{UVN}$ increased the number of GAD $67^{+}$exclusively on the deafferented side (365.1 cells, $p<0.0001$ vs both the sham group and the intact side). In contrast, a significant and symmetrical bilateral increase $(p<0.0001)$ was observed in the UVN-BDNF group (intact side: 368.2 cells, deafferented side: 372.0 cells) and a smaller but significant increase of GAD67 ${ }^{+}$cells was also detected in the deafferented MVN of the UVN-K252a group compared with the sham group (186.4 cells, $p<0.0001$; Fig. $2 A, D$ ).
Overall, this finding suggests that, in vestibular pathological conditions, BDNF modulates cholinergic and GABAergic neuromodulation in the $\mathrm{VN}$ complexes.

\section{BDNF influences the cell differentiation pattern of newborn cells in the deafferented VN}

The new cells that survived more than several weeks after UVN are supposed to differentiate and to acquire a neurochemical phenotype $\sim 20 \mathrm{~d}$ after birth. Cell differentiation was investigated by double immunohistochemical labeling using BrdU combined with one of the four cell-type-specific markers: GFAP, NeuN, IBA1, or GAD67. To avoid the possibility that cells being $\mathrm{BrdU}^{+}$/ $\mathrm{IBA}^{+}{ }^{+}$reflects phagocytosis of dying proliferating cells by micro- 


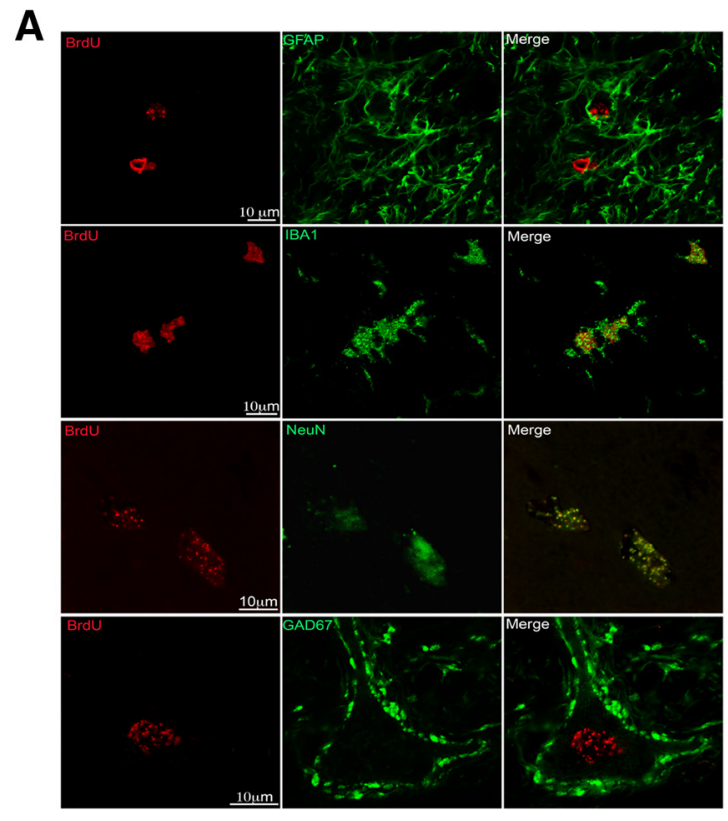

B

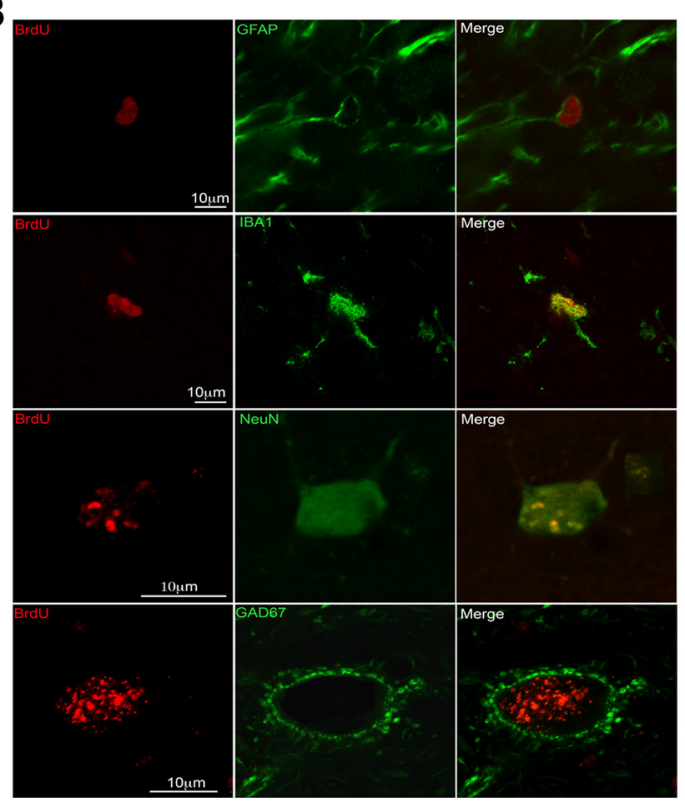

C

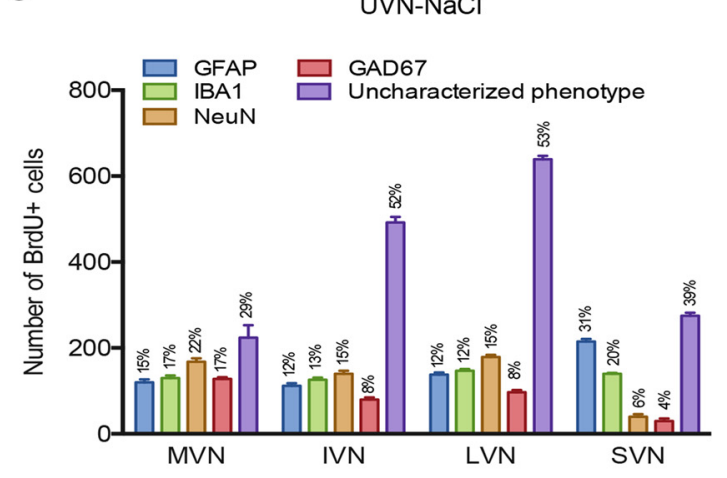

U UVN-BDNF

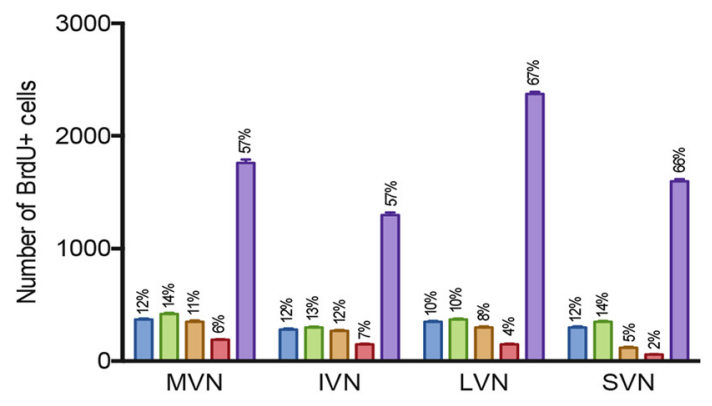

E

UVN-K252a

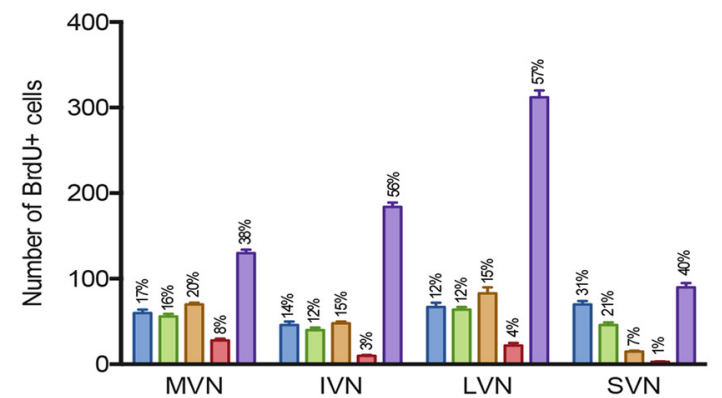

Figure 5. BDNF influences the cell differentiation pattern of newborn cells in the deafferented VN. Confocal analysis of differentiated newly generated cells by double immunostainings processed on consecutive serial sections in the deafferented MVN of cats infused with BDNF $(\boldsymbol{A})$ or K252a $(\boldsymbol{B})$ infusion from days $0-30$ after UVN. The BrdU ${ }^{+}$nuclei are shown in red and the other markers of differentiation (GFAP, IBA1, NeuN, and GAD67) are shown in green. Histograms illustrating the percentage are defined as the ratio between the mean number of immunopostive elements colocalizing a cell-type marker (GFAP, IBA1, NeuN, or GAD 67) and BrdU relative to the total mean number of BrdU ${ }^{+}$nuclei counted in the areas of quantification of the UVN-NaCl (C), UVN-BDNF (D), or UVN-K252a (E) groups. SEMs are shown as vertical lines.

glia, we counted only $\mathrm{IBA}^{+}$cells that displayed the typical ramified morphology and in which BrdU staining was in the center of the cell. As already described (Tighilet et al., 2007), no colocalization of $\mathrm{BrdU}^{+} / \mathrm{ChAT}^{+}$was found in any group (data not shown), suggesting that newly generated cells in the deafferented VN did not differentiate into cholinergic neurons.

The photomicrographs in Figure 5, $A$ and $B$, show the colocalization of BrdU with GFAP, NeuN, IBA1, and GAD67 cells observed in the deafferented MVN at day 30 after lesion in the UVN-BDNF (Fig. 5A) and UVN-K252a (Fig. 5B) groups. As described previously (Dutheil et al., 2013), in the UVN-NaCl group, the newly generated cells differentiated approximately in similar proportion in all the $\mathrm{VN}$ (Fig. $5 \mathrm{C}$ ). Many of the $\mathrm{BrdU}^{+}$cells were double-immunolabeled with NeuN in all experimental groups, indicating that some new cells differentiated into new nonGABAergic neurons and acquired a different neuronal phenotype (Fig. $5 C-E$ ). As for the UVN NaCl-group, when BDNF was infused for $30 \mathrm{~d}$, the newly generated cells differentiated approximately in similar proportion in the MVN (12\% GFAP, $14 \%$ IBA1, and $11 \%$ NeuN, respectively), IVN $(12 \%, 13 \%$, and $12 \%$, respectively), and $\mathrm{LVN}(10 \%, 10 \%$, and $8 \%$, respectively) (Fig. $5 A, D)$. In contrast, in the SVN, GFAP and IBA1 labeling were higher (12\% and $14 \%$, respectively) than NeuN labeling (5\%). Interestingly, a larger soma surface with an enhanced dendritic branching of $\mathrm{BrdU}^{+} / \mathrm{GAD} 7^{+}$cells was observed in the group treated with BDNF (Fig. 5A) compared with those treated with 
$\mathrm{K} 252 \mathrm{a}$, where $\mathrm{BrdU}^{+} / \mathrm{GAD}^{+} 7^{+}$cells exhibited both smaller soma and dendritic fields (Fig. $5 B$ ). As for the rate of cell proliferation and survival, the number of $\mathrm{BrdU}^{+}$cells that differentiated into astrocytes $\left(\mathrm{BrdU}^{+} / \mathrm{GFAP}^{+}\right.$cells $)$, neurons $\left(\mathrm{BrdU}^{+} /\right.$ $\mathrm{NeuN}^{+}$cells), microglial $\left(\mathrm{BrdU}^{+} / \mathrm{IBA1}^{+}\right.$cells $)$, and GABAergic neurons $\left(\mathrm{BrdU}^{+} / \mathrm{GAD} 7^{+}\right)$was four times greater in the UVNBDNF group and two times lower in the UVN-K252a group compared with the UVN-NaCl group. Overall, these findings show that, in all the experimental groups, the newly generated cells differentiated in the four different lineages approximately in similar proportion in all $\mathrm{VN}$.

\section{KCC2 and $\mathrm{GABA}_{\mathrm{A}} \mathrm{R}$ expression are modulated by the vestibular lesion and by $B D N F$ infusion}

To determine how BDNF can accelerate vestibular functional recovery, we studied some of the local microenvironment changes that could influence network excitability in the first $3 \mathrm{~d}$ after UVN. We focused our analysis on the giant neurons of the LVN because it contains excitatory glutamatergic neuronsinvolved in vestibulospinal pathways regulating posturo-locomotor functions. Two specific markers of neuronal excitability were selected: the cationchloride cotransporters KCC2, which determines the hyperpolarizing action of GABA, and $\mathrm{GABA}_{\mathrm{A}} \mathrm{Rs}$. In the $\mathrm{UVN}-\mathrm{NaCl}$ group, we observed a significant decrease of KCC2 expression in the deafferented (ipsilateral) side ( $-32 \%$ vs sham group, $p<0.05$; Fig. $6 A, B$ ), whereas a significant increase was found in the intact (contralateral) side ( $+28 \%$ vs sham group, $p<0.05$ ), revealing a significant asymmetry between the two sides of the VN complex $(p<0.001)$ in this short time window. In addition, $\mathrm{GABA}_{\mathrm{A}} \mathrm{R}$ expression was significantly increased in both the lesioned side $(+88 \%, p<0.0001)$ and the intact side $(+186 \%, p<0.0001)$ of the UVN-NaCl animals.

BDNF infusion did not alter KCC2 expression $3 \mathrm{~d}$ after UVN compared with the sham group, but did induce a bilateral downregulation of the $\mathrm{GABA}_{\mathrm{A}} \mathrm{R}$ that was significant in the intact side compared with shams $(-43 \%, p<0.001$; Fig. $6 A, B)$. A significant decrease in $\mathrm{GABA}_{\mathrm{A}} \mathrm{R}$ expression was also observed in the intact side compared with the deafferented side of UVN-BDNF animals $(-23 \%, p<0.005)$. Therefore, BDNF seems to be involved in the regulation of $\mathrm{GABA}_{\mathrm{A}} \mathrm{R}$ expression in an early time window after UVN (days 1-3). Interestingly, blocking the action of endogenous BDNF by K252a infusion during these first $3 \mathrm{~d}$ after UVN led to a significant bilateral increase of KCC2 and $\mathrm{GABA}_{\mathrm{A}} \mathrm{R}$ expression in the deafferented side $(+70 \%, p<0.05$ for KCC2 and $+100 \%, p<0.001$ for $\left.\mathrm{GABA}_{\mathrm{A}} \mathrm{R}\right)$ and the intact side $(+128 \%, p<0.001$ for KCC2 and $+183 \%, p<0.0001$ for $\left.\mathrm{GABA}_{\mathrm{A}} \mathrm{R}\right)$ compared with shams. Overall, this suggests that blocking BDNF action after UVN increases both KCC2 and $\mathrm{GABA}_{\mathrm{A}} \mathrm{R}$ immunolabeling.

\section{Discussion}

We report here for the first time that BDNF potentiates vestibular neurogenesis and accelerates functional recovery after vestibular injury. We also show that KCC2 and GABA $\mathrm{Rs}$ undergo remarkable fluctuations within the $\mathrm{VN}$, suggesting that GABA acquires a transient depolarizing action in the VN during the recovery period. This novel plasticity mechanism could explain in part how the VN returns to electrophysiological homeostasis, considered in the literature to be a key parameter of vestibular compensation.

Neurotrophins and their TrK receptors are widely distributed in the main VN in mammals (Furukawa et al., 1998; Zhang et al., 2003, 2007; Lacour and Tighilet, 2010). Here, we show that BDNF treatment accelerates the restoration of oculomotor and posturo-locomotor functions. Consistent with these experiments, a previous study of intra-VN administration of BDNF in the guinea pig showed decreased spontaneous nystagmus after vestibular damage (Maingay et al., 2000). Moreover, we found that TrkB blockade delays the recovery of all impaired functions, especially posturo-locomotor activity, as described in another study conducted in guinea pigs showing that BDNF blockade delayed postural compensation after unilateral labyrinthectomy (Bolger et al., 1999). Therefore, vestibular compensation time course is strongly accelerated by local action of BDNF in the VN.

We have shown that BDNF and its receptor TrkB are strongly upregulated at $3 \mathrm{~d}$ after UVN in the deafferented VN, which coincides with the highest production rate of newborn cells (Lacour and Tighilet, 2010). Here, we show that continuous BDNF administration into the fourth ventricle after UVN significantly increases the production of newly generated cells, confirming the proneurogenic properties of this growth factor in vivo. Similarly, a previous study showed that BDNF infusion into the lateral ventricle of the adult rat leads to new neurons in the striatum, septum, thalamus, and hypothalamus (Pencea et al., 2001). Next, we used K252a and showed that it strongly attenuated the proneurogenic action of UVN. One month after the lesion, we observed that BDNF increased cell survival compared with saline, whereas K252atreated animals had the lowest rate of cell survival and did not achieve complete vestibular compensation. More specifically, we observed that newborn GABAergic neurons exhibited both smaller soma and dendritic fields in K252a-treated animals, whereas these cells exhibited a larger soma surface with enhanced dendritic branching in the UVN-BDNF group. Axon growth and dendrite development are key processes for the establishment of a functional neuronal network and it was reported recently that dendritic branching is BDNF dependent (Ribeiro et al., 2015). Together, our results demonstrate that BDNF action through TrkB receptors amplifies cell proliferation, survival, and development of functional dendritic branching in the deafferented $\mathrm{VN}$ of the vestibular-lesioned cats. We suggest that BDNF may contribute to the integration of newborn neurons into functional networks, which would favor the behavioral recovery.

Astrocyte-expressed factors are known to modulate neural progenitor cell differentiation (Song et al., 2002; GonzalezPerez and Quiñones-Hinojosa, 2012) and are potent regulators of synapse formation, tuning, and maintenance in both developing and adult brain (Xu et al., 2009; Roberts et al., 2010; Chung et al., 2013). Microglia are also involved in synapse elimination and can release various neurotrophic and anti-inflammatory factors favoring cell proliferation, survival, and regeneration (Aguzzi et al., 2013; Cherry et al., 2014). M2-like microglial activation has been shown to be protective and to belong to the healthy neurogenic niche in vitro by maintaining normal neuronal precursor cell activity (Butovsky et al., 2006; Walton et al., 2006). In addition, environmental enrichment known to increase neurogenesis is accompanied by an increase in anti-inflammatory-type microglia (Ziv et al., 2006). Likewise, in this study, we observed an increase in both astrocytes and microglia concurrently with the formation of new neurons at day 3 after UVN that were all promoted by BDNF and reduced by K252a. We hypothesize that astrocytes and microglia promote a benefic environment for neurogenesis in our model and could also remodel the synaptic environment by removing unwanted and dysfunctional synapses uncorrelated to activity. Such a mechanism 
A

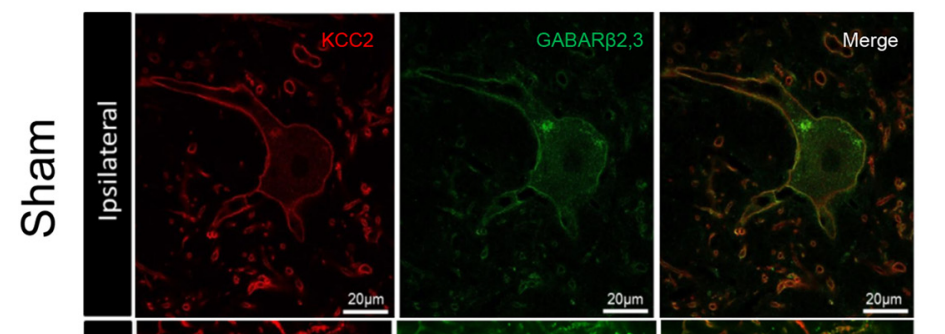

B

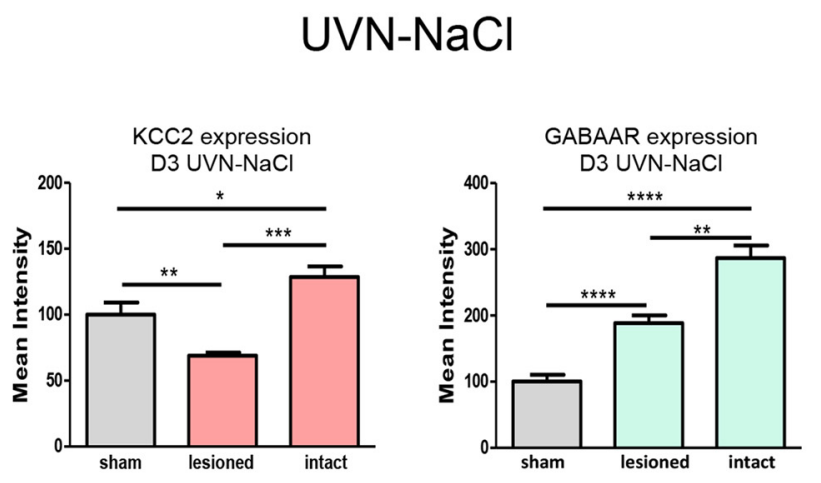

\section{UVN-BDNF}
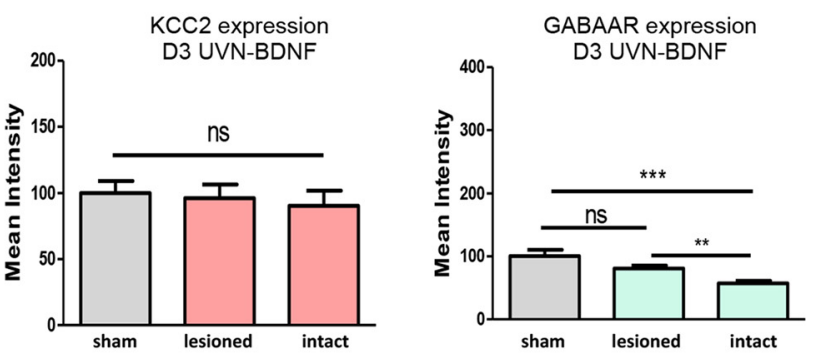

\section{UVN-K252a}

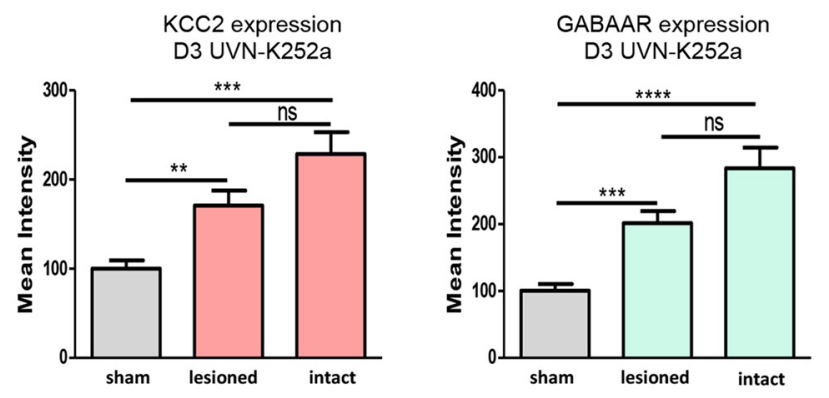

Figure 6. $K C C 2$ and $G A B A_{A} R$ expression is modulated either by vestibular lesion and BDNF infusion. $A$, Confocal analysis of neurons immunostained with either the $K C C 2$ or $G A B A_{A} R$ located in the contralateral (intact) and ipsilateral (lesioned) lateral VN of sham or UVN animals infused with NaCl, BDNF, or K252a from days $0-3$ after UVN. Scale bar, $20 \mu \mathrm{m} . n=4$ animals per group. $\boldsymbol{B}$, Histograms showing the effects of $\mathrm{NaCl}, \mathrm{BDNF}$, or K252a continuous infusion on $\mathrm{KCC} 2$ or $G A B A_{A}$ R immunostainings in both intact and lesioned lateral VN $3 \mathrm{~d}$ after UVN. SEMs are shown as vertical lines. Data from both sides of sham group were pooled for direct comparison with the subgroups of vestibular deafferented cats. *Significant differences between groups of animals or between lesioned versus intact side in the same animal in the UVN-NaCl, UVN-BDNF, and UVN-K252a groups. ${ }^{*} p<0.005$; ${ }^{* *} p<0.001 ;{ }^{* * *} p<0.0001$. 


\section{Three days after Unilateral Vestibular Neurectomy (UVN)}

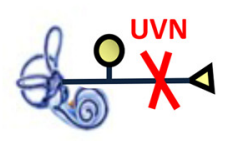

Deafferented side

of the vestibular nuclei

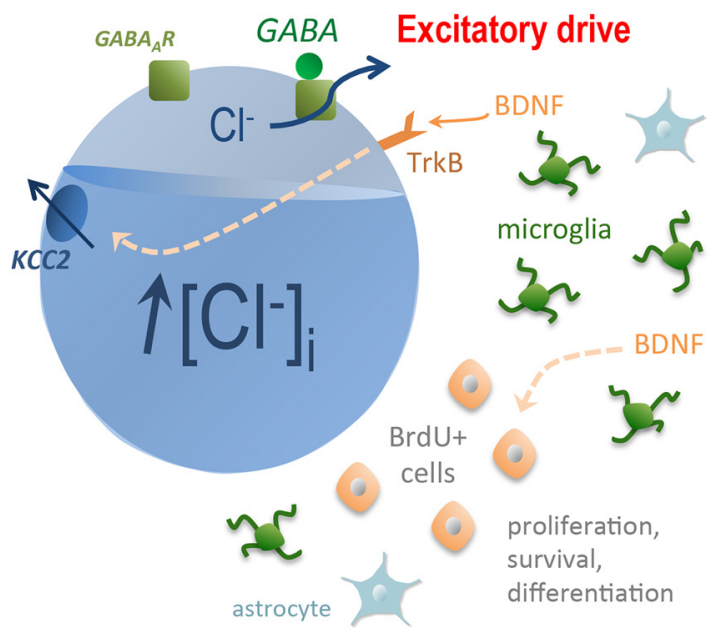

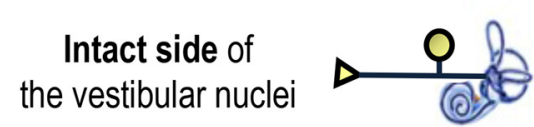

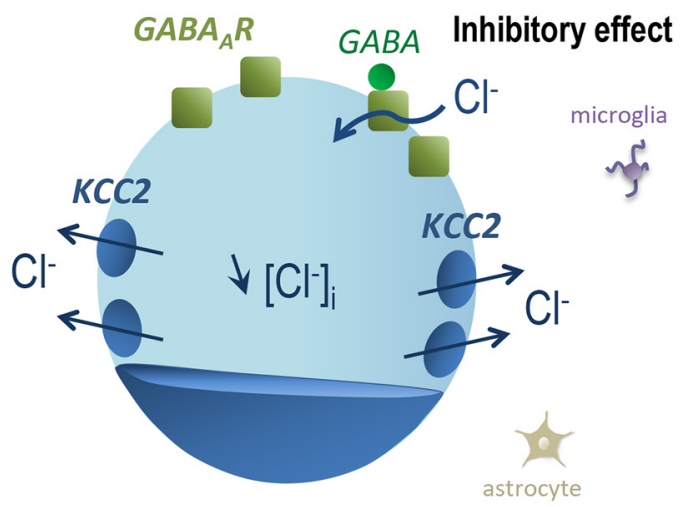

Figure 7. Summary of the cascade of events underlying modulation of chloride homeostasis in the deafferented VN after UVN. In the adult, in physiological conditions or on the intact side of the VN (right side), the presence of $\mathrm{KCC}$ on the cells leads to a low $\left[\mathrm{Cl}^{-}\right]_{i}$ concentration. When $\mathrm{GABA}$ activates $\mathrm{GABA}_{A} \mathrm{R}$, it then triggers a hyperpolarizing action through the influx of $\mathrm{Cl}^{-}$. After $\mathrm{UVN}$ (left side), microglia and astrocytes are strongly upregulated in the deafferented VN. We hypothesize that microglia, as well as nerve terminals, release BDNF, which in turn activates TrkB receptors and downregulates KCC2 expression. A lower concentration in KCC2 then decreases the chloride extrusion capacity of the cell; $\left[\mathrm{Cl}^{-}\right]_{i}$ then accumulates and causes a collapse in the transmembrane chloride gradient. The anion flux being inverted, $\mathrm{GABA}_{\mathrm{A}} \mathrm{R}$ activation leads, in such conditions, to an efflux of $\mathrm{Cl}^{-}$, thus increasing the excitability of the cells. Interestingly, at the same time point ( $3 \mathrm{~d}$ after UVN), a peak of BrdU ${ }^{+}$cells is observed on the lesioned side of the VN and is correlated with a peak of BDNF expression as well. This suggests that BDNF, released by both neurons and glia, could modulate cell proliferation, survival, and excitability.

would shape neuronal networks and help to keep the most efficient connections to rebalance electrical activity between the deafferented and intact VN.

We have shown that the expression of cholinergic neurons increases after UVN, but newly generated neurons do not acquire a cholinergic phenotype (Tighilet and Lacour, 1998; Tighilet et al., 2007). This observation suggests that, after deafferentation, ChAT protein expression is upregulated locally. In the present study, we confirmed this result and also show that, $30 \mathrm{~d}$ after lesion, BDNF infusion potentiated this effect. Likewise, it has been described that BDNF enhances acetylcholine release (Auld et al., 2001) and promotes a cholinergic phenotype in basal forebrain neurons (Nonner et al., 2000) through a TrkB-dependent mechanism (Burgess and Aubert, 2006). Interestingly, ACh agonists and acetylcholinesterase inhibitors have also been found to increase the firing activity of $\mathrm{VN}$ neurons in vitro and in vivo through muscarinic and nicotinic receptors (Yamamoto, 1967; Ujihara et al., 1989; Phelan and Gallagher, 1992). Therefore, we strongly suggest that BDNF-TrkB signaling causes the upregulation of ChAT expression in the ipsilateral VN of the BDNF-UVN group and may help rebalance the activity between the ipsilateral and contralateral VN, which is considered to be a pivotal step in behavioral recovery.

GABAergic transmission is essential for healthy brain physiology during development and throughout adult life; any discrepancy between excitation and inhibition can cause severe pathological conditions such as epilepsy (Ben-Ari, 2014). Recent evidence indicates that GABAergic signaling alters post-UVNrelated plasticity mechanisms occurring in the $\mathrm{VN}$ and can influence directly the time course of vestibular compensation (Dutheil et al., 2013). Consistent with our previous studies (Tighilet and
Lacour, 2001; Dutheil et al., 2009, 2011, 2013), we confirm here that UVN promotes proliferation of GABAergic neurons exclusively on the ipsilateral side, which likely helps to rebalance the ratio of excitation to inhibition between the two VN. Surprisingly, we observed that BDNF infusion led to a symmetric increase of GABAergic neurons in both the intact and lesioned VN, whereas a TrkB receptor antagonist blocked this effect. TrkB and its ligand, BDNF, could modulate GABAergic transmission in the $\mathrm{VN}$, as demonstrated in the rat hippocampus (Frerking et al., 1998) and mouse cerebellum (Rico et al., 2002). These data imply that BDNF and GABA both facilitate a return to electrophysiological homeostasis between the $\mathrm{VN}$ on the deafferented and intact sides, which is a key component of vestibular functional recovery.

Restoration of vestibular neurons' excitability on the deafferented side is known to be a key parameter for functional recovery (Lacour and Tighilet, 2010). It is also well accepted that the excitability level of the local environment significantly affects adult neurogenesis (Chun et al., 2006; Segi-Nishida et al., 2008; Kokaia, 2011). We thus examined how the TrKB-BDNF signaling pathway can accelerate vestibular compensation, focusing on two neuronal markers that reflect the level of excitability: the cationchloride cotransporter KCC2 and the $\mathrm{GABA}_{\mathrm{A}} \mathrm{R}$. Downregulation of KCC2 has been shown to decrease the chloride extrusion capacity of the cell, which leads to intracellular accumulation of $\left[\mathrm{Cl}^{-}\right]$ions and thus induces a depolarizing outward chloride current from $\mathrm{GABA}_{\mathrm{A}}$ Rs in response to GABA (Coull et al., 2003, 2005), as illustrated in Figure 7. Here, we show that whereas $\mathrm{GABA}_{\mathrm{A}} \mathrm{R}$ expression is increased on both sides of the LVN $3 \mathrm{~d}$ after UVN in lesioned cats infused with saline, KCC2 expression is asymmetrical (i.e., decreased in the lesioned LVN and in- 
creased in the intact LVN). Consistent with this result, several studies have shown a decreased KCC2 expression after a different type of lesion in the adult mammal brain (Cramer et al., 2008; Mòdol et al., 2014a, 2014b), thus triggering a reduction in KCC2 expression responsible for an increase in local neurons' excitability (i.e., a depolarizing response to GABA; Nabekura et al., 2002; Toyoda et al., 2003; Kahle et al., 2008; Boulenguez et al., 2010; Sadlaoud et al., 2010).

In addition, the microglia-BDNF-TrkB signaling also appears to be able to shift neurons toward a more excitable state. Under nerve injury conditions, microglia become activated (McMahon et al., 2005) and express purinergic P2X4 receptors (Tsuda et al., 2003). Stimulation of P2X4 receptors cause microglia to secrete BDNF, which in turn acts on TrkB receptors' neurons that downregulate KCC2 (Rivera et al., 2002, 2004; Ferrini and De Koninck, 2013), thus decreasing the chloride extrusion capacity of the cell. A similar mechanism could be envisioned in our UVN model, in which microglia are significantly upregulated in the deafferented VN. BDNF would act on TrkB receptors and cause an excitatory action of GABA through the observed downregulation of KCC2 expression. Interestingly, it has been shown that blockade of microglia-BDNF-TrkB signaling at the spinal level caused a return of $\mathrm{E}_{\mathrm{GABA}}$ to more negative values in spinal cord slices from rats with established allodynia (Coull et al., 2005). Consistent with this, our results showed a downregulation of microglia in the $\mathrm{VN}$ of the UVN cats in which BDNF action was blocked, combined with an upregulation of both KCC2 and $\mathrm{GABA}_{\mathrm{A}} \mathrm{R}$ expression. Behaviorally, this group showed a very slow and incomplete functional recovery. We therefore suggest that blocking BDNF action and its cellular consequences on KCC2 and $\mathrm{GABA}_{\mathrm{A}} \mathrm{R}$ expression causes a strong inhibitory action of GABA in the vestibular environment of these animals, which is responsible for their slower and incomplete compensation. In contrast, because we found that, $3 \mathrm{~d}$ after UVN, BDNF infusion downregulated $\mathrm{GABA}_{\mathrm{A}} \mathrm{R}$ and did not induce KCC2 expression changes in the LVN, we believe that bilateral reduction of $\mathrm{GABA}_{\mathrm{A}} \mathrm{R}$ immunoreactivity is likely to reflect a reduction of local inhibition that seems beneficial for vestibular compensation. Collectively, the data described here reveal that KCC2 modulation appears to be a novel and important mechanism contributing to vestibular compensation through the restoration of spontaneous activity in the deafferented VN. Our results also highlight a short therapeutic critical time window between 1 and $3 \mathrm{~d}$ after UVN when some markers of excitability are locally altered and during which the effects of pharmacological treatments are likely to be more efficient.

In conclusion, this study provides new information about the remarkable plastic changes in the structural organization and functional properties of neuronal circuits during vestibular compensation. It highlights the importance of both BDNF and KCC2 in the normalization of local excitability through $\mathrm{GABA}_{\mathrm{A}} \mathrm{Rs}$, which could represent a novel treatment strategy.

\section{References}

Aguzzi A, Barres BA, Bennett ML (2013) Microglia: scapegoat, saboteur, or something else? Science 339:156-161. CrossRef Medline

Auld DS, Mennicken F, Day JC, Quirion R (2001) Neurotrophins differentially enhance acetylcholine release, acetylcholine content and choline acetyltransferase activity in basal forebrain neurons. J Neurochem 77: 253-262. CrossRef Medline

Ben-Ari Y (2014) The GABA excitatory/inhibitory developmental se- quence: a personal journey. Neuroscience 279:187-219. CrossRef Medline

Bergami M, Rimondini R, Santi S, Blum R, Götz M, Canossa M (2008) Deletion of TrkB in adult progenitors alters newborn neuron integration into hippocampal circuits and increases anxiety-like behavior. Proc Natl Acad Sci U S A 105:15570-15575. CrossRef Medline

Berman AL (1968) The brain stem of the cats: a cytoarchitechtonic atlas with stereotaxic coordinates. Madison, WI: Wisconsin University.

Bolger C, Sansom AJ, Smith PF, Darlington CL (1999) An antisense oligonucleotide to brain-derived neurotrophic factor delays postural compensation following unilateral labyrinthectomy in guinea pig. Neuroreport 10:1485-1488. CrossRef Medline

Bos R, Sadlaoud K, Boulenguez P, Buttigieg D, Liabeuf S, Brocard C, Haase G, Bras H, Vinay L (2013) Activation of 5-HT2A receptors upregulates the function of the neuronal K-Cl cotransporter KCC2. Proc Natl Acad Sci U S A 110:348-353. CrossRef Medline

Boulenguez P, Liabeuf S, Bos R, Bras H, Jean-Xavier C, Brocard C, Stil A, Darbon P, Cattaert D, Delpire E, Marsala M, Vinay L (2010) Downregulation of the potassium-chloride cotransporter KCC2 contributes to spasticity after spinal cord injury. Nat Med 16:302-307. CrossRef Medline Brezun JM, Daszuta A (2000) Serotonin may stimulate granule cell proliferation in the adult hippocampus, as observed in rats grafted with foetal raphe neurons. Eur J Neurosci 12:391-396. CrossRef Medline

Burgess A, Aubert I (2006) Polysialic acid limits choline acetyltransferase activity induced by brain-derived neurotrophic factor. J Neurochem 99 : 797-806. CrossRef Medline

Butovsky O, Ziv Y, Schwartz A, Landa G, Talpalar AE, Pluchino S, Martino G, Schwartz M (2006) Microglia activated by IL-4 or IFN-gamma differentially induce neurogenesis and oligodendrogenesis from adult stem/progenitor cells. Mol Cell Neurosci 31:149-160. CrossRef Medline

Cass SP, Goshgarian HG (1990) Increased glial fibrillary acidic protein immunoreactivity in astrocytes within the lateral vestibular nucleus of the cat following labyrinthectomy and vestibular neurectomy. Ann Otol Rhinol Laryngol 99:221-227. Medline

Cherry JD, Olschowka JA, O’Banion MK (2014) Neuroinflammation and M2 microglia: the good, the bad, and the inflamed. J Neuroinflammation 11:98. CrossRef Medline

Chun SK, Sun W, Park JJ, Jung MW (2006) Enhanced proliferation of progenitor cells following long-term potentiation induction in the rat dentate gyrus. Neurobiol Learn Mem 86:322-329. CrossRef Medline

Chung WS, Clarke LE, Wang GX, Stafford BK, Sher A, Chakraborty C, Joung J, Foo LC, Thompson A, Chen C, Smith SJ, Barres BA (2013) Astrocytes mediate synapse elimination through MEGF10 and MERTK pathways. Nature 504:394-400. CrossRef Medline

Coull JA, Boudreau D, Bachand K, Prescott SA, Nault F, Sík A, De Koninck P, De Koninck Y (2003) Trans-synaptic shift in anion gradient in spinal lamina I neurons as a mechanism of neuropathic pain. Nature 424: 938-942. CrossRef Medline

Coull JA, Beggs S, Boudreau D, Boivin D, Tsuda M, Inoue K, Gravel C, Salter MW, De Koninck Y (2005) BDNF from microglia causes the shift in neuronal anion gradient underlying neuropathic pain. Nature 438:10171021. CrossRef Medline

Cramer SW, Baggott C, Cain J, Tilghman J, Allcock B, Miranpuri G, Rajpal S, Sun D, Resnick D (2008) The role of cation-dependent chloride transporters in neuropathic pain following spinal cord injury. Mol Pain 4:36. CrossRef Medline

Dieringer N (1995) "Vestibular compensation": neural plasticity and its relations to functional recovery after labyrinthine lesions in frogs and other vertebrates. Prog Neurobiol 46:97-129. Medline

Dutheil S, Brezun JM, Leonard J, Lacour M, Tighilet B (2009) Neurogenesis and astrogenesis contribution to recovery of vestibular functions in the adult cat following unilateral vestibular neurectomy: cellular and behavioral evidence. Neuroscience 164:1444-1456. CrossRef Medline

Dutheil S, Lacour M, Tighilet B (2011) Neurogenic potential of the vestibular nuclei and behavioural recovery time course in the adult cat are governed by the nature of the vestibular damage. PLoS One 6:e22262. CrossRef Medline

Dutheil S, Escoffier G, Gharbi A, Watabe I, Tighilet B (2013) GABA(A) receptor agonist and antagonist alter vestibular compensation and different steps of reactive neurogenesis in deafferented vestibular nuclei of adult cats. J Neurosci 33:15555-15566. CrossRef Medline

Ernfors P, Lee KF, Jaenisch R (1994) Mice lacking brain-derived neu- 
rotrophic factor develop with sensory deficits. Nature 368:147-150. CrossRef Medline

Ferrini F, De Koninck Y (2013) Microglia control neuronal network excitability via BDNF signalling. Neural Plast 2013:429815. CrossRef

Frerking M, Malenka RC, Nicoll RA (1998) Brain-derived neurotrophic factor (BDNF) modulates inhibitory, but not excitatory, transmission in the CA1 region of the hippocampus. J Neurophysiol 80:3383-3386. Medline

Fritzsch B, Silos-Santiago I, Bianchi LM, Fariñas I (1997) The role of neurotrophic factors in regulating the development of inner ear innervation. Trends Neurosci 20:159-164. CrossRef Medline

Furukawa S, Sugihara Y, Iwasaki F, Fukumitsu H, Nitta A, Nomoto H, Furukawa Y (1998) Brain-derived neurotrophic factor-like immunoreactivity in the adult rat central nervous system predominantly distributed in neurons with substantial amounts of brain-derived neurotrophic factor messenger RNA or responsiveness to brain-derived neurotrophic factor. Neuroscience 82:653-670. Medline

Gonzalez-Perez O, Quiñones-Hinojosa A (2012) Astrocytes as neural stem cells in the adult brain. J Stem Cells 7:181-188. CrossRef Medline

Greenberg ME, Xu B, Lu B, Hempstead BL (2009) New insights in the biology of BDNF synthesis and release: implications in CNS function. J Neurosci 29:12764-12767. CrossRef Medline

Kahle KT, Staley KJ, Nahed BV, Gamba G, Hebert SC, Lifton RP, Mount DB (2008) Roles of the cation-chloride cotransporters in neurological disease. Nat Clin Pract Neurol 4:490-503. CrossRef Medline

Kokaia M (2011) Seizure-induced neurogenesis in the adult brain. Eur J Neurosci 33:1133-1138. CrossRef Medline

Lacour M (2006) Restoration of vestibular function: basic aspects and practical advances for rehabilitation. Curr Med Res Opin 22:1651-1659. CrossRef Medline

Lacour M, Tighilet B (2010) Plastic events in the vestibular nuclei during vestibular compensation: the brain orchestration of a "deafferentation" code. Restor Neurol Neurosci 28:19-35. CrossRef Medline

Lacour M, Roll JP, Appaix M (1976) Modifications and development of spinal reflexes in the alert baboon (Papio papio) following an unilateral vestibular neurotomy. Brain Res 113:255-269. CrossRef Medline

Lee J, Duan W, Mattson MP (2002) Evidence that brain-derived neurotrophic factor is required for basal neurogenesis and mediates, in part, the enhancement of neurogenesis by dietary restriction in the hippocampus of adult mice. J Neurochem 82:1367-1375. CrossRef Medline

Li YX, Hashimoto T, Tokuyama W, Miyashita Y, Okuno H (2001) Spatiotemporal dynamics of brain-derived neurotrophic factor mRNA induction in the vestibulo-olivary network during vestibular compensation. J Neurosci 21:2738-2748. Medline

Lucas EK, Jegarl A, Clem RL (2014) Mice lacking TrkB in parvalbuminpositive cells exhibit sexually dimorphic behavioral phenotypes. Behav Brain Res 274:219-225. CrossRef Medline

Maingay MG, Sansom AJ, Kerr DR, Smith PF, Darlington CL (2000) The effects of intra-vestibular nucleus administration of brain-derived neurotrophic factor (BDNF) on recovery from peripheral vestibular damage in guinea pig. Neuroreport 11:2429-2432. Medline

McMahon SB, Cafferty WB, Marchand F (2005) Immune and glial cell factors as pain mediators and modulators. Exp Neurol 192:444-462. CrossRef Medline

Mòdol L, Cobianchi S, Navarro X (2014a) Prevention of NKCC1 phosphorylation avoids downregulation of KCC2 in central sensory pathways and reduces neuropathic pain after peripheral nerve injury. Pain 155:15771590. CrossRef Medline

Mòdol L, Mancuso R, Alé A, Francos-Quijorna I, Navarro X (2014b) Differential effects on KCC2 expression and spasticity of ALS and traumatic injuries to motoneurons. Front Cell Neurosci 8:7. CrossRef Medline

Nabekura J, Ueno T, Okabe A, Furuta A, Iwaki T, Shimizu-Okabe C, Fukuda A, Akaike N (2002) Reduction of KCC2 expression and GABAA receptor-mediated excitation after in vivo axonal injury. J Neurosci 22: 4412-4417. Medline

Nonner D, Barrett EF, Barrett JN (2000) Brief exposure to neurotrophins produces a calcium-dependent increase in choline acetyltransferase activity in cultured rat septal neurons. J Neurochem 74:988-999. CrossRef Medline

Park H, Poo MM (2013) Neurotrophin regulation of neural circuit development and function. Nat Rev Neurosci 14:7-23. CrossRef Medline
Pencea V, Bingaman KD, Wiegand SJ, Luskin MB (2001) Infusion of brainderived neurotrophic factor into the lateral ventricle of the adult rat leads to new neurons in the parenchyma of the striatum, septum, thalamus, and hypothalamus. J Neurosci 21:6706-6717. Medline

Phelan KD, Gallagher JP (1992) Direct muscarinic and nicotinic receptormediated excitation of rat medial vestibular nucleus neurons in vitro. Synapse 10:349-358. CrossRef Medline

Ribeiro FF, Neves-Tomé R, Assaife-Lopes N, Santos TE, Silva RFM, Brites D, Ribeiro JA, Sousa MM, Sebastião AM (2015) Axonal elongation and dendritic branching is enhanced by adenosine $\mathrm{A} 2 \mathrm{~A}$ receptors activation in cerebral cortical neurons. Brain Struct Funct. Advance online publication. Retrieved May 9, 2016. doi: 10.1007/s00429-015-1072-1. CrossRef

Rico B, Xu B, Reichardt LF (2002) TrkB receptor signaling is required for establishment of GABAergic synapses in the cerebellum. Nat Neurosci 5:225-233. CrossRef Medline

Ris L, Godaux E (1998) Neuronal activity in the vestibular nuclei after contralateral or bilateral labyrinthectomy in the alert guinea pig. J Neurophysiol 80:2352-2367. Medline

Ris L, de Waele C, Serafin M, Vidal PP, Godaux E (1995) Neuronal activity in the ipsilateral vestibular nucleus following unilateral labyrinthectomy in the alert guinea pig. J Neurophysiol 74:2087-2099. Medline

Rivera C, Li H, Thomas-Crusells J, Lahtinen H, Viitanen T, Nanobashvili A, Kokaia Z, Airaksinen MS, Voipio J, Kaila K, Saarma M (2002) BDNFinduced TrkB activation down-regulates the $\mathrm{K}^{+}-\mathrm{Cl}^{-}$cotransporter KCC2 and impairs neuronal $\mathrm{Cl}^{-}$extrusion. J Cell Biol 159:747-752. CrossRef Medline

Rivera C, Voipio J, Thomas-Crusells J, Li H, Emri Z, Sipila S, Payne JA, Minichiello L, Saarma M, Kaila K (2004) Mechanism of activitydependent downregulation of the neuron-specific $\mathrm{K}-\mathrm{Cl}$ cotransporter KCC2. J Neurosci 24:4683-4691. CrossRef Medline

Roberts TF, Tschida KA, Klein ME, Mooney R (2010) Rapid spine stabilization and synaptic enhancement at the onset of behavioural learning. Nature 463:948-952. CrossRef Medline

Sadlaoud K, Tazerart S, Brocard C, Jean-Xavier C, Portalier P, Brocard F, Vinay L, Bras H (2010) Differential plasticity of the GABAergic and glycinergic synaptic transmission to rat lumbar motoneurons after spinal cord injury. J Neurosci 30:3358-3369. CrossRef Medline

Sairanen M, Lucas G, Ernfors P, Castrén M, Castrén E (2005) Brain-derived neurotrophic factor and antidepressant drugs have different but coordinated effects on neuronal turnover, proliferation, and survival in the adult dentate gyrus. J Neurosci 25:1089-1094. CrossRef Medline

Schimmang T, Minichiello L, Vazquez E, San Jose I, Giraldez F, Klein R, Represa J (1995) Developing inner ear sensory neurons require TrkB and TrkC receptors for innervation of their peripheral targets. Development 121:3381-3391. Medline

Segi-Nishida E, Warner-Schmidt JL, Duman RS (2008) Electroconvulsive seizure and VEGF increase the proliferation of neural stem-like cells in rat hippocampus. Proc Natl Acad Sci U S A 105:11352-11357. CrossRef Medline

Smith PF, Darlington CL (1991) Neurochemical mechanisms of recovery from peripheral vestibular lesions (vestibular compensation). Brain Res Brain Res Rev 16:117-133. CrossRef Medline

Song H, Stevens CF, Gage FH (2002) Astroglia induce neurogenesis from adult neural stem cells. Nature 417:39-44. CrossRef Medline

Tighilet B, Lacour M (1998) Distribution of choline acetyltransferase immunoreactivity in the vestibular nuclei of normal and unilateral vestibular neurectomized cats. Eur J Neurosci 10:3115-3126. CrossRef Medline

Tighilet B, Lacour M (2001) Gamma amino butyric acid (GABA) immunoreactivity in the vestibular nuclei of normal and unilateral vestibular neurectomized cats. Eur J Neurosci 13:2255-2267. CrossRef Medline

Tighilet B, Trottier S, Mourre C, Lacour M (2006) Changes in the histaminergic system during vestibular compensation in the cat. J Physiol 573: 723-739. CrossRef Medline

Tighilet B, Brezun JM, Sylvie GD, Gaubert C, Lacour M (2007) New neurons in the vestibular nuclei complex after unilateral vestibular neurectomy in the adult cat. Eur J Neurosci 25:47-58. CrossRef Medline

Toyoda H, Ohno K, Yamada J, Ikeda M, Okabe A, Sato K, Hashimoto K, Fukuda A (2003) Induction of NMDA and GABAA receptor-mediated $\mathrm{Ca} 2+$ oscillations with KCC2 mRNA downregulation in injured facial motoneurons. J Neurophysiol 89:1353-1362. Medline 
Tsuda M, Shigemoto-Mogami Y, Koizumi S, Mizokoshi A, Kohsaka S, Salter MW, Inoue K (2003) P2X4 receptors induced in spinal microglia gate tactile allodynia after nerve injury. Nature 424:778-783. CrossRef Medline

Ujihara H, Akaike A, Sasa M, Takaori S (1989) Muscarinic regulation of spontaneously active medial vestibular neurons in vitro. Neurosci Lett 106:205-210. CrossRef Medline

Vidal PP, de Waele C, Vibert N, Mühlethaler M (1998) Vestibular compensation revisited. Otolaryngol Head Neck Surg 119:34-42. CrossRef Medline

Walton NM, Sutter BM, Laywell ED, Levkoff LH, Kearns SM, Marshall GP 2nd, Scheffler B, Steindler DA (2006) Microglia instruct subventricular zone neurogenesis. Glia 54:815-825. CrossRef Medline

Waterhouse EG, An JJ, Orefice LL, Baydyuk M, Liao GY, Zheng K, Lu B, Xu B (2012) BDNF promotes differentiation and maturation of adult-born neurons through GABAergic transmission. J Neurosci 32:14318-14330. CrossRef Medline

West MJ, Slomianka L, Gundersen HJ (1991) Unbiased stereological estimation of the total number of neurons in thesubdivisions of the rat hippocampus using the optical fractionator. Anat Rec 231:482-497. CrossRef Medline

Xerri C, Lacour M (1980) Compensation deficits in posture and kinetics following unilateral vestibular neurectomy in cats: the role of sensorimo- tor activity [article in French]. Acta Otolaryngol 90:414-424. CrossRef Medline

Xu T, Yu X, Perlik AJ, Tobin WF, Zweig JA, Tennant K, Jones T, Zuo Y (2009) Rapid formation and selective stabilization of synapses for enduring motor memories. Nature 462:915-919. CrossRef Medline

Yamamoto C (1967) Pharmacologic studies of norepinephrine, acetylcholine and related compounds on neurons in Deiters' nucleus and the cerebellum. J Pharmacol Exp Ther 156:39-47. Medline

Zennou-Azogui Y, Borel L, Lacour M, Ez-Zaher L, Ouaknine M (1993) Recovery of head postural control following unilateral vestibular neurectomy in the cat: neck muscle activity and neuronal correlates in Deiters' nuclei. Acta Otolaryngol Suppl 509:1-19. Medline

Zhang FX, Lai CH, Lai SK, Yung KK, Shum DK, Chan YS (2003) Neurotrophin receptor immunostaining in the vestibular nuclei of rats. Neuroreport 14:851-855. CrossRef Medline

Zhang HT, Li LY, Zou XL, Song XB, Hu YL, Feng ZT, Wang TT (2007) Immunohistochemical distribution of NGF, BDNF, NT-3, and NT-4 in adult rhesus monkey brains. J Histochem Cytochem 55:1-19. Medline

Ziv Y, Ron N, Butovsky O, Landa G, Sudai E, Greenberg N, Cohen H, Kipnis J, Schwartz M (2006) Immune cells contribute to the maintenance of neurogenesis and spatial learning abilities in adulthood. Nat Neurosci 9:268-275. CrossRef Medline 